\title{
Contaminating melt flow in magmatic peridotites from the lower continental crust (Rocca d'Argimonia sequence, Ivrea-Verbano Zone)
}

\author{
Marta Antonicelli ${ }^{1}$, Riccardo Tribuzio ${ }^{1,2}$, Tong $\mathrm{Liu}^{3}$, and Fu-Yuan $\mathrm{Wu}^{3}$ \\ ${ }^{1}$ Dipartimento di Scienze della Terra e dell'Ambiente, Università degli Studi di Pavia, \\ via Ferrata 1, 27100 Pavia, Italy \\ ${ }^{2}$ Istituto di Geoscienze e Georisorse, C.N.R., Unità di Pavia, via Ferrata 1, 27100 Pavia, Italy \\ ${ }^{3}$ Institute of Geology and Geophysics, Chinese Academy of Sciences, \\ Beituchengxilu 19, Chaoyang, Beijing, China \\ Correspondence: Riccardo Tribuzio (tribuzio@crystal.unipv.it)
}

Received: 19 May 2020 - Revised: 14 October 2020 - Accepted: 23 October 2020 - Published: 4 November 2020

\begin{abstract}
The lower continental crust section of the Ivrea-Verbano Zone (Italian Alps) was intruded by a $\sim 8 \mathrm{~km}$ thick gabbroic-dioritic body (Ivrea Mafic Complex) in the Upper Carboniferous-Lower Permian, in conjunction with the post-collisional transtensional regime related to the Variscan orogeny. In the deepest levels of the Ivrea Mafic Complex, several peridotite-pyroxenite sequences considered of magmatic origin are exposed. We present here a petrological-geochemical investigation of the peridotites from the largest magmatic ultramafic sequence of the Ivrea Mafic Complex, locally called Rocca d'Argimonia. In spite of the widespread subsolidus re-equilibration under granulite facies conditions, most likely reflecting a slow cooling evolution in the lower continental crust, the Rocca d'Argimonia peridotites (dunites to harzburgites and minor clinopyroxene-poor lherzolites) typically retain structures and microstructures of magmatic origin. In particular, the harzburgites and the lherzolites typically show poikilitic orthopyroxenes enclosing partially dissolved olivine and minor spinel. Olivine has forsterite proportion diminishing from the dunites to the harzburgites and the lherzolites $(90 \mathrm{~mol} \%$ to $85 \mathrm{~mol} \%)$ and negatively correlating with $\delta^{18} \mathrm{O}(+5.8 \%$ o to $+6.6 \%$ o). Gabbronorite dykes locally crosscut the peridotites and show millimetre-scale thick, orthopyroxenite to websterite reaction zones along the contact with host rocks. We propose that the Rocca d'Argimonia peridotites record a process of reactive melt flow through a melt-poor olivine-rich crystal mush or a pre-existing dunite. This process was most likely responsible for the olivine dissolution shown by the poikilitic orthopyroxenes in the harzburgites-lherzolites. We infer that the reactively migrating melts possessed a substantial crustal component and operated at least at the scale of $\sim 100 \mathrm{~m}$.
\end{abstract}

\section{Introduction}

The processes driving the chemical differentiation of primitive magmas emplaced in the deep sectors of the continental crust are largely unknown. Several recent studies have proposed that the melt evolution in large magma reservoirs predominantly occurs by reactive flow in melt-poor crystal mushes (e.g. Lissenberg and MacLeod, 2016; Jackson et al., 2018). In the lower continental crust, in particular, the intrusion of primitive mantle magmas is expected to generate a region of crystal mush, in which the melt phase may also orig- inate, to a minor extent, from partial melting of the crust (see also Solano et al., 2012). Within mushy magma chambers, buoyant melts are inferred to percolate upwards along crystal boundaries, transporting chemical components and modifying the structure and the chemistry of pre-existing crystals. Other studies conversely support the idea that magma evolution in large magmatic systems is controlled by fractional crystallization in long-lived, liquid-dominated magma chambers (e.g. Kruger and Latypov, 2020).

The Ivrea Mafic Complex of the Ivrea-Verbano Zone (Italian Alps) is an excellent natural laboratory to assess the lower 


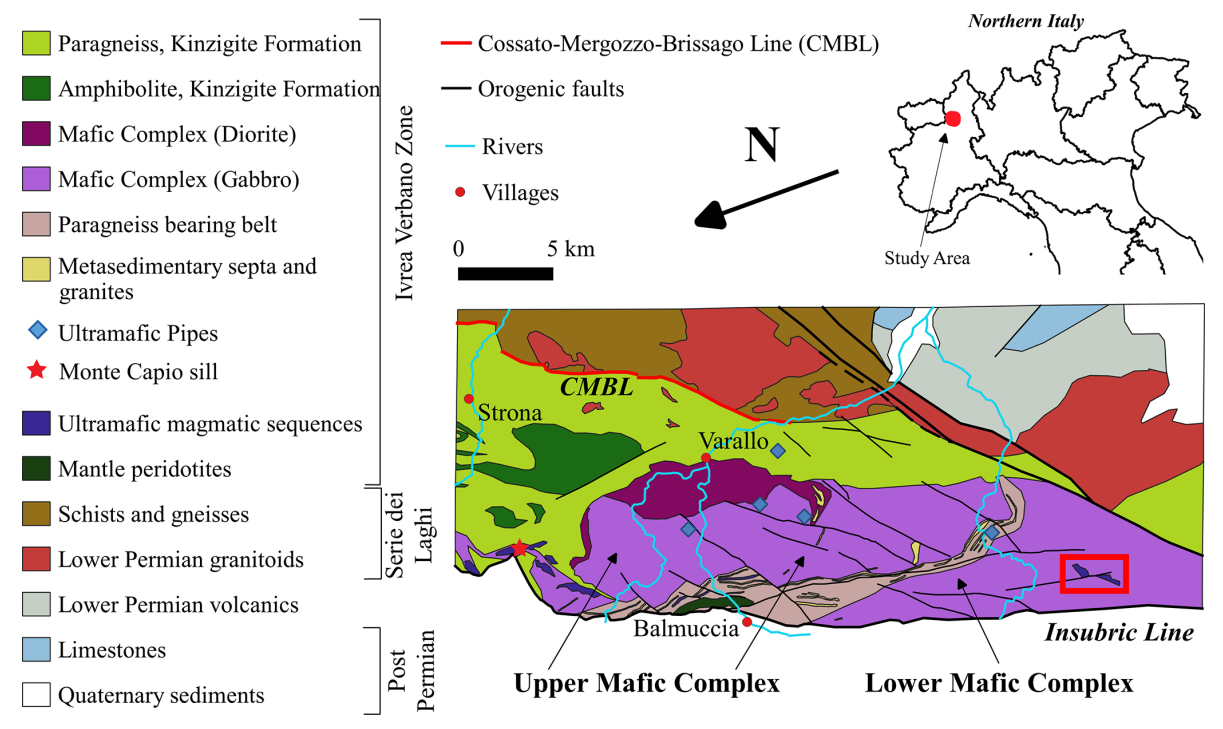

Figure 1. Geological map of the central Ivrea-Verbano Zone and Serie dei Laghi, simplified after Sinigoi et al. (2016). Location of the ultramafic pipes after Guergouz et al. (2018). The north orientation aims at elucidating the inferred Permian stratigraphy. The red frame refers to the location of the Rocca d'Argimonia sequence (see Fig. 2).

crust processes associated with the development of crustalscale magmatic systems (Quick et al., 1992; Sinigoi et al., 2011, 2016; Solano et al., 2014; Jackson et al., 2018). The Ivrea Mafic Complex consists of a $\sim 8 \mathrm{~km}$ thick gabbroicdioritic intrusion, developed in conjunction with the postcollisional transtensional regime of the Variscan orogeny (e.g. Handy et al., 1999; Wilson et al., 2004). In its deepest levels, the Ivrea Mafic Complex includes several peridotitepyroxenite sequences considered of magmatic origin (e.g. Quick et al., 2003), whose petrological characteristics are poorly known.

The present study wishes to provide new insights into the processes governing the evolution of primitive mantle magmas emplaced in the lower continental crust. For this purpose, we carried out a petrological-geochemical investigation of the peridotites from the largest magmatic ultramafic sequence exposed within the Ivrea Mafic Complex, which is locally referred to as Rocca d'Argimonia (Lensch, 1968; Bertolani and Loschi Ghittoni, 1979). This sequence comprises peridotites characterized by the widespread occurrence of poikilitic orthopyroxenes. Similar microstructures in other ultramafic magmatic sequences from the upper continental crust have been recently related to an open-system magmatic evolution driven by reactive melt flow (Barnes et al., 2016; Kaufmann et al., 2018) or by wall-rock crustal contamination (Mao et al., 2019). We also acquired relevant information about the Rocca d'Argimonia peridotite-forming processes by investigating orthopyroxene-rich reaction zones that developed along the contacts between the peridotites and crosscutting gabbronorite dykes.

Based on petrographic observations and mineral/wholerock major element chemistry, we propose that the develop- ment of orthopyroxene in the Rocca d'Argimonia peridotites was related to reactive melt flow through a melt-poor olivinerich crystal mush or a pre-existing dunite. Because the peridotite olivines show significant variations in oxygen isotopic signature, we also infer that the reactively migrating melts possessed a substantial crustal component.

\section{Geological framework}

The Ivrea-Verbano Zone (Fig. 1) from the inner arc of western Italian Alps exposes a nearly complete section of the pre-Alpine, lower continental crust (e.g. Sinigoi et al., 2016; Pistone et al., 2017). To the west and northwest, the Ivrea-Verbano Zone is in tectonic contact with the Austroalpine domain, which typically exhibits widespread tectono-metamorphic transformations related to the Alpine orogenic evolution (e.g. Schmid, 2017), through the Insubric tectonic lineament. To the south and southeast, two tectonic lineaments, namely the Cossato-Mergozzo-Brissago and the Pogallo Lines, separate the Ivrea-Verbano Zone from the Serie dei Laghi, which represents the upper section of the preAlpine continental crust (e.g. Boriani and Giobbi, 2004).

The southwestern sector of the Ivrea-Verbano Zone (Fig. 1) consists of a $\sim 8 \mathrm{~km}$ thick gabbroic-dioritic sequence (Ivrea Mafic Complex) intruding a granulite to amphibolite facies basement (e.g. Quick et al., 1992; Sinigoi et al., 2011), in conjunction with the post-collisional transtensional regime related to the Variscan orogeny (e.g. Handy et al., 1999; Wilson et al., 2004). The basement, locally known as Kinzigite Formation, is made up of metasediments (metapelites with subordinate metagreywackes and impure marbles), minor metabasites and, locally, mantle peridotite blocks (e.g. 
Quick et al., 1995; Redler et al., 2013). In the Val Strona di Omegna section, adjacent to the northern termination of the Ivrea Mafic Complex, the basement rocks show pressure and temperature conditions gradually diminishing from $\sim 0.9 \mathrm{GPa}$ and $\sim 940^{\circ} \mathrm{C}$ near the Insubric Line to $\sim 0.5 \mathrm{GPa}$ and $\sim 650{ }^{\circ} \mathrm{C}$ near the Cossato-Mergozzo-Brissago line (see also Kunz and White, 2019). The onset of this metamorphic gradient and the main phase of Ivrea Mafic Complex formation were inferred to occur at $316 \pm 3 \mathrm{Ma}$ (Ewing et al., 2013) and $283.5 \pm 2.3 \mathrm{Ma}$ (Karakas et al., 2019).

The Ivrea Mafic Complex (Fig. 1) was subdivided into two stratigraphically overlying units (Quick et al., 2003). The lower Ivrea Mafic Complex is mostly composed of amphibole gabbros that make up the southwestern sector of the intrusion. It includes the peridotite-pyroxenite sequence of Rocca d'Argimonia (Lensch, 1968; Bertolani and Loschi Ghittoni, 1979), which was considered of magmatic origin (see also Sinigoi et al., 1991). The upper Ivrea Mafic Complex mainly consists of gabbronorites and, towards the roof, diorites. The lowest level of the upper Ivrea Mafic Complex, also referred to as "paragneiss-bearing belt", comprises metasedimentary septa and peridotite-pyroxenite silllike bodies (Rivalenti et al., 1975; Voshage et al., 1990; Sinigoi et al., 1995; 1996). The metasedimentary septa are interpreted as remnants of the Kinzigite Formation that underwent substantial extraction of $\mathrm{SiO}_{2}$-rich melts in response to the interaction with melts forming the Ivrea Mafic Complex. The paragneiss-bearing belt also encloses a huge mantle sequence defining a $4.5 \mathrm{~km}$ long and $0.8 \mathrm{~km}$ wide lens, which is known as Balmuccia peridotite massif (Quick et al., 1995). This mantle sequence is mostly made up of clinopyroxenepoor lherzolites (e.g. Shervais and Mukasa, 1991) containing replacive dunite bodies (Mazzucchelli et al., 2009) and two major sets of pyroxenite veins dominated by either $\mathrm{Cr}$ diopside or Al-augite (e.g. Voshage et al., 1988; Rivalenti et al., 1995; Mukasa and Shervais, 1999).

Towards the top of the Ivrea Mafic Complex and within the Kinzigite Formation, discordant peridotite-pyroxenite bodies (up to $300 \mathrm{~m}$ wide), typically amphibole- and phlogopitebearing, are exposed (Garuti et al., 2001). They are collectively known as the ultramafic pipes and most likely formed by primitive alkaline magmas at $288-249 \mathrm{Ma}$ (see also Locmelis et al., 2016; Fiorentini et al., 2018). Along the northern edge of the Ivrea Mafic Complex, near the Insubric Line, several sill-like peridotite-pyroxenite sequences (up to kilometre scale in length) crop out (Ferrario et al., 1983; Zaccarini et al., 2014). These peridotite-pyroxenite sequences, also collectively known as Monte Capio sill, are relatively rich in amphibole and phlogopite-free and formed by $\mathrm{H}_{2} \mathrm{O}$ rich basaltic melts that intruded the lowermost continental crust of the Ivrea-Verbano Zone (Berno et al., 2020). The age of these peridotite-pyroxenite sequences is debated. Klötzli et al. (2014) proposed an age of $314 \pm 5 \mathrm{Ma}$ based on U$\mathrm{Pb}$ analyses of zircons separated from an amphibole-garnet gabbro, which could be however genetically unrelated to the peridotite-pyroxenite sequence. Denyszyn et al. (2018) reported a U-Pb zircon age of $\sim 200 \mathrm{Ma}$, which could also be referred to as a zircon recrystallization event, as observed for zircons from other deep levels of the Ivrea-Verbano Zone (e.g. Vavra et al., 1999; Zanetti et al., 2016; Langone et al., 2017).

\section{The Rocca d'Argimonia sequence: field relationships}

The Rocca d'Argimonia ultramafic rocks are enclosed within gabbronorites, which are in turn embedded in the amphibole gabbros of the lower Ivrea Mafic Complex (Quick et al., 2003). In particular, two major ultramafic rock bodies, characterized by up to $100 \mathrm{~m}$ thick peridotite-pyroxenite alternations, are exposed near Bielmonte village (Fig. 2).

The peridotites are locally characterized by the widespread occurrence of poikilitic orthopyroxenes, typically $0.5-2.0 \mathrm{~cm}$ in size (Fig. 3a). The poikilitic orthopyroxenes are in places aligned to define a foliation that is subparallel to the inferred orientation of the peridotite-pyroxenite surface contacts (Fig. 2). Olivine-depleted bands, characteristically a few tens of centimetres thick, are locally associated with the peridotites rich in poikilitic orthopyroxene. The pyroxenites are plagioclase-bearing, medium-grained rocks that are modally dominated by orthopyroxene (see also Bertolani and Loschi Ghittoni, 1979).

The peridotites are crosscut by up to $0.3 \mathrm{~m}$ thick gabbronorite dykes with sharp planar boundaries (Fig. 3b). The dykes are oriented at a high angle with respect to the orthopyroxene foliation of host peridotites. The gabbronoriteperidotite contact is characterized by a $3-5 \mathrm{~mm}$ thick pyroxene-rich zone. Sinuous gabbronorite dykelets $(\leq 2 \mathrm{~cm}$ thick) also occur in places, in both the peridotites and adjacent pyroxenites. Subparallel to the contact surface with host peridotites, the gabbronorite dykes exhibit a layering defined by grain size and/or plagioclase/pyroxene modal variations and, locally, a foliation defined by weak alignment of plagioclase and pyroxene. Some of the dykes show pyroxenes elongated nearly perpendicularly to the wall peridotite surface.

\section{Analytical methods}

Whole-rock major element analyses of selected peridotites and gabbronorite dykes (Table 1) were carried out at Activation Laboratories (Ancaster, Ontario), following commercial package 4Lithores. Sample preparation implies a lithium metaborate-tetraborate fusion and digestion in 5\% nitric acid. Analyses of $\mathrm{SiO}_{2}, \mathrm{Al}_{2} \mathrm{O}_{3}, \mathrm{Fe}_{2} \mathrm{O}_{3}, \mathrm{MnO}, \mathrm{MgO}$, $\mathrm{CaO}, \mathrm{Na}_{2} \mathrm{O}, \mathrm{K}_{2} \mathrm{O}, \mathrm{TiO}_{2}$ and $\mathrm{P}_{2} \mathrm{O}_{5}$ were performed by inductively coupled plasma optical emission spectroscopy. $\mathrm{Cr}_{2} \mathrm{O}_{3}$ and $\mathrm{NiO}$ contents were measured by inductively coupled plasma mass spectroscopy. Detection limits are $0.01 \mathrm{wt} \%$ for $\mathrm{SiO}_{2}, \mathrm{Al}_{2} \mathrm{O}_{3}, \mathrm{Fe}_{2} \mathrm{O}_{3}, \mathrm{MgO}, \mathrm{CaO}, \mathrm{Na}_{2} \mathrm{O}, \mathrm{K}_{2} \mathrm{O}$ and $\mathrm{P}_{2} \mathrm{O}_{5}$, 


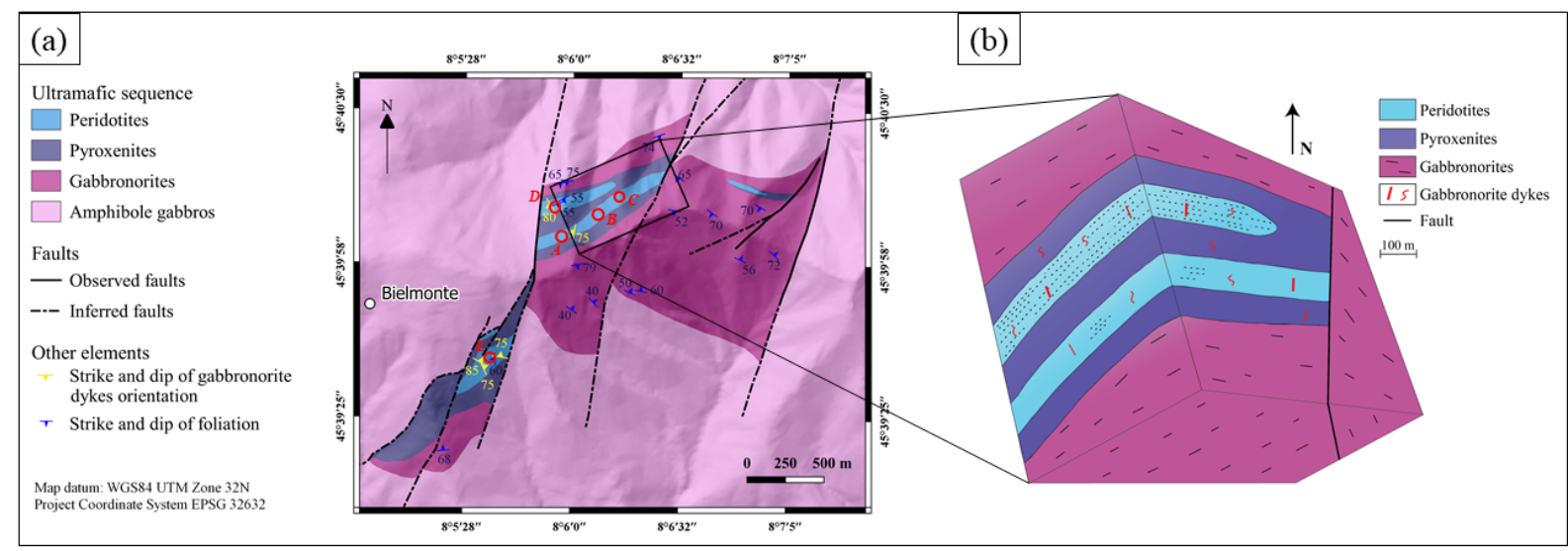

Figure 2. (a) Geological map of the Rocca d'Argimonia area, compiled after Lensch (1968) and Quick et al. (2003), and new field investigations. The empty dots represent the sampling sites. A: peridotites BI10/1 and BI10/3, and gabbronorite BI10/3; B: peridotites BI4/1 and $\mathrm{BI} 4 / 3$; C: peridotite BI5/1; D: peridotites BI2/1, BI2/5, BI2/7, BI6/2 and BI30/5, and gabbronorites BI2/5 and BI8/1; E: gabbronorite BI50/3. Location of Bielmonte village is also reported. (b) Synthetic block diagram illustrating the relationships between the different rock types of the Rocca d'Argimonia sequence; the dotted lines within the peridotites represent domains rich in poikilitic orthopyroxene.

Table 1. Whole-rock chemical compositions of selected samples.

\begin{tabular}{|c|c|c|c|c|c|c|c|c|c|c|c|c|c|}
\hline Sample & $\mathrm{BI} 4 / 3$ & $\mathrm{BI} 4 / 1$ & $\mathrm{BI} 10 / 3$ & BI10/1 & $\mathrm{BI} 5 / 1$ & $\mathrm{BI} 2 / 1$ & $\mathrm{BI} 2 / 7$ & $\mathrm{BI} 6 / 2$ & $\mathrm{BI} 30 / 5$ & $\mathrm{BI} 2 / 5$ & $\mathrm{BI} 10 / 3$ & BI8/1 & $\mathrm{BI} 50 / 3$ \\
\hline Rock type & & & Dunites & & & \multicolumn{2}{|c|}{ Harzburgites } & \multicolumn{2}{|c|}{ Lherzolites } & \multicolumn{4}{|c|}{ Gabbronorite dykes } \\
\hline $\mathrm{SiO}_{2}$ & 38.2 & 38.4 & 39.3 & 39.2 & 37.1 & 39.5 & 40.1 & 43.5 & 44.7 & 45.9 & 47.8 & 49.1 & 47.0 \\
\hline $\mathrm{Al}_{2} \mathrm{O}_{3}$ & 1.48 & 1.51 & 1.39 & 1.40 & 3.00 & 2.66 & 1.75 & 3.30 & 4.86 & 21.3 & 12.5 & 18.4 & 19.3 \\
\hline $\mathrm{Fe}_{2} \mathrm{O}_{3}$ (tot) & 10.4 & 10.5 & 12.1 & 12.7 & 12.4 & 13.0 & 13.3 & 12.5 & 13.0 & 4.04 & 6.69 & 6.50 & 7.27 \\
\hline $\mathrm{MnO}$ & 0.14 & 0.14 & 0.16 & 0.16 & 0.15 & 0.17 & 0.17 & 0.17 & 0.18 & 0.07 & 0.13 & 0.12 & 0.13 \\
\hline $\mathrm{MgO}$ & 47.5 & 47.5 & 45.3 & 45.8 & 43.2 & 42.6 & 42.2 & 35.6 & 34.0 & 11.0 & 15.4 & 10.0 & 10.3 \\
\hline $\mathrm{CaO}$ & 0.92 & 0.96 & 0.75 & 0.82 & 1.38 & 1.17 & 0.63 & 3.42 & 1.67 & 14.1 & 16.0 & 12.7 & 12.6 \\
\hline $\mathrm{Na}_{2} \mathrm{O}$ & 0.05 & 0.05 & 0.04 & 0.04 & 0.06 & 0.06 & 0.04 & 0.13 & 0.10 & 1.27 & 0.68 & 1.57 & 1.61 \\
\hline $\mathrm{K}_{2} \mathrm{O}$ & $<0.01$ & $<0.01$ & $<0.01$ & $<0.01$ & $<0.01$ & $<0.01$ & $<0.01$ & $<0.01$ & $<0.01$ & 0.06 & 0.05 & 0.13 & 0.12 \\
\hline $\mathrm{TiO}_{2}$ & 0.05 & 0.05 & 0.04 & 0.05 & 0.09 & 0.10 & 0.05 & 0.17 & 0.19 & 0.33 & 0.43 & 0.40 & 0.39 \\
\hline $\mathrm{Cr}_{2} \mathrm{O}_{3}$ & 0.64 & 0.65 & 0.59 & 0.52 & 1.27 & 0.88 & 0.92 & 0.41 & 0.70 & 0.02 & 0.10 & 0.02 & 0.01 \\
\hline $\mathrm{NiO}$ & 0.31 & 0.31 & 0.27 & 0.28 & 0.34 & 0.24 & 0.23 & 0.16 & 0.18 & 0.08 & 0.08 & 0.03 & 0.02 \\
\hline $\mathrm{P}_{2} \mathrm{O}_{5}$ & 0.01 & $<0.01$ & $<0.01$ & $<0.01$ & $<0.01$ & 0.01 & 0.01 & $<0.01$ & 0.02 & $<0.01$ & $<0.01$ & $<0.01$ & $<0.01$ \\
\hline LOI & $<0.01$ & 0.20 & 0.11 & $<0.01$ & 1.12 & 0.05 & 0.46 & 0.83 & 0.52 & 1.80 & 0.92 & 0.95 & 2.03 \\
\hline Total & 99.7 & 100.2 & 100.0 & 100.9 & 100.0 & 100.4 & 99.8 & 100.1 & 100.1 & 100.0 & 100.7 & 99.8 & 100.8 \\
\hline Mg\# & 90.1 & 90.0 & 88.1 & 87.8 & 87.4 & 86.7 & 86.3 & 84.9 & 83.8 & 84.4 & 82.0 & 75.2 & 73.7 \\
\hline
\end{tabular}

$0.001 \mathrm{wt} \%$ for $\mathrm{MnO}$ and $\mathrm{TiO}_{2}$, and $0.003 \mathrm{wt} \%$ for $\mathrm{Cr}_{2} \mathrm{O}_{3}$ and $\mathrm{NiO}$.

The main mineral phases (olivine, orthopyroxene, clinopyroxene, amphibole spinel and plagioclase) of the selected rock samples were analysed for $\mathrm{Si}, \mathrm{Ti}, \mathrm{Al}, \mathrm{Cr}, \mathrm{Fe}, \mathrm{Mn}, \mathrm{Ni}$, $\mathrm{Mg}, \mathrm{Ca}, \mathrm{Na}$ and $\mathrm{K}$ with an electron microprobe (JEOL 8200 Super Probe) at Dipartimento di Scienze della Terra, Università degli Studi di Milano, in wavelength-dispersive spectrometry mode. Electron microprobe operating conditions were $15 \mathrm{kV}$ accelerating voltage and $5 \mathrm{nA}$ beam current, with counting times of $30 \mathrm{~s}$ on the peaks and $10 \mathrm{~s}$ on the backgrounds. We used a $\sim 1 \mu \mathrm{m}$ focused beam and natural minerals as standards, namely grossular for $\mathrm{Si}, \mathrm{Ca}$ and $\mathrm{Al}$; fayalite for $\mathrm{Fe}$; forsterite-rich olivine for $\mathrm{Mg}$; rhodonite for $\mathrm{Mn}$; il- menite for Ti; omphacite for Na; K-feldspar for K; niccolite for $\mathrm{Ni}$; and pure chromium metal for $\mathrm{Cr}$.

Oxygen isotopic compositions of olivine from selected peridotites (Table 8) were analysed in situ using CAMECA IMS-1280 ion microprobe at the Institute of Geology and Geophysics - Chinese Academy of Sciences, Beijing. Olivine grains were separated and embedded in epoxy, adjacent to grains of a San Carlos olivine standard. The Cs+ primary beam was accelerated at $10 \mathrm{kV}$ with an intensity of $\sim 1.5 \mathrm{nA}$. The spot size was $10-15 \mu \mathrm{m}$ in diameter. An electron gun was used to compensate for sample charging during analysis. Secondary ions were extracted with $\mathrm{a} \sim 10 \mathrm{kV}$ potential. Oxygen isotopes were measured in multi-collector mode with two off-axis Faraday cups with each analysis consisting of 16 cycles $\times 4 \mathrm{~s}$ counting time. The instrumen- 

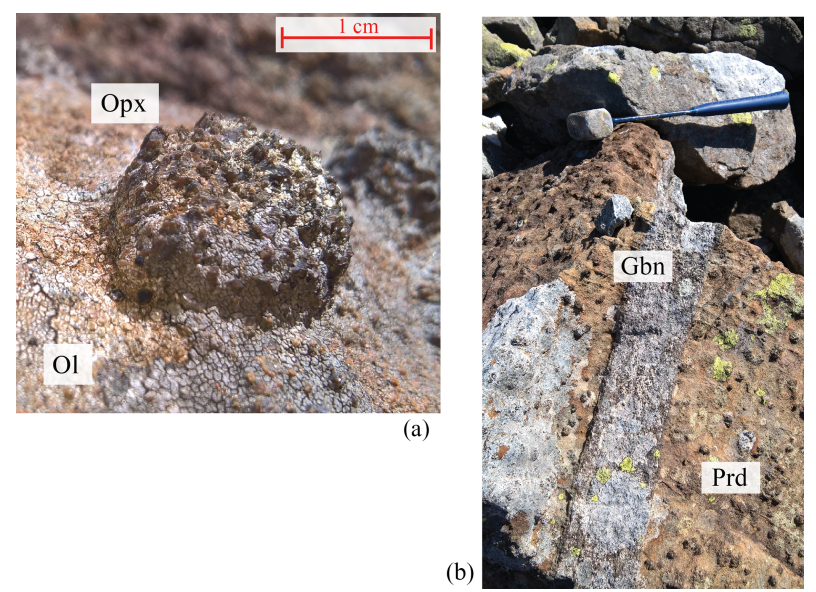

Figure 3. (a) Poikilitic orthopyroxene ( $\sim 1 \mathrm{~cm}$ in diameter) in a peridotite, evidenced by the preferential erosion of host olivine-rich matrix. (b) Gabbronorite dyke (Gbn) displaying sharp planar contacts against host peridotite (Prd), in turn displaying poikilitic orthopyroxenes.

tal mass fractionation factor is corrected using San Carlos olivine standard with $\delta^{18} \mathrm{OVSMOW}_{\text {VSM }}=5.25 \% \circ \pm 0.05$ (Eiler et al., 1995). Point-to-point uncertainty for $\delta^{18} \mathrm{O}$ was typically $<0.4 \%$ o (2 SE). For each peridotite, oxygen isotopic analyses were conducted at the core of 18-20 olivine grains. The measured $\delta^{18} \mathrm{O}_{\text {VSMOW }}$ of the San Carlos olivine standard during this study is $5.27 \% \circ \pm 0.12$ (95\% confidence level, $n=20)$.

\section{Results}

The main petrographic characteristics and GPS coordinates of rock samples selected for the present study are reported in Table 9. Location of samples is also shown in Fig. 2a. Mineral proportions were evaluated based on mass balance calculations, combining whole-rock and mineral chemical compositions. In particular, we used a least squares mixing programme to reproduce the whole-rock chemistry based on compositions of the minerals constituting the rock (see Table 9 caption for details about calculations). Computed whole-rock compositions based on observed mineral compositions and estimated mineral proportions are listed in Table A1.

\subsection{Peridotites}

\subsubsection{Petrographic characteristics}

The peridotites free of poikilitic orthopyroxene are dunites (Fig. 4a). They mostly consist of olivine polygonal grains (average size $2-3 \mathrm{~mm}$ ) defining a nearly granoblastic structure and include accessory clinopyroxene, spinel, amphibole and orthopyroxene. Clinopyroxene, spinel and amphibole grains are smaller than olivine grains (Table 9) and typically display nearly equant morphology. Spinel also occurs within olivine, with subhedral to euhedral morphology. Orthopyroxene ( 1 vol \%-5 vol \%) has variable grain size and, characteristically, anhedral morphology. It may form small grains interstitial among olivines to large grains with anhedral morphology (up to $7 \mathrm{~mm}$ in thin section).

The peridotites rich in poikilitic orthopyroxenes ( $7 \mathrm{vol} \%-$ $15 \mathrm{vol} \%$ ) are harzburgites (Fig. 4a). The poikilitic orthopyroxenes enclose a substantial amount of olivine and minor spinel (Fig. 5a). In particular, modal point counting applied to poikilitic orthopyroxenes showed that olivine and spinel correspond to $35 \mathrm{vol} \%-40 \mathrm{vol} \%$ and $6 \mathrm{vol} \%-9 \mathrm{vol} \%$, respectively, of the orthopyroxene volume. Olivine within poikilitic orthopyroxene shows variable grain size, rounded to elliptical shape, and frequent embayed boundaries. Conversely, olivine external to poikilitic orthopyroxenes is nearly equigranular and with polygonal morphology. Within a single poikilitic orthopyroxene, the elliptical olivine inclusions are locally subparallel. A single orthopyroxene may also host olivine clusters showing the same optical orientation, thereby indicating that they were part of a pre-existing larger olivine grain. Spinel within and external to poikilitic orthopyroxenes typically has similar grain size and nearly equant morphology. Spinel occurring along the contact between olivine and enclosing orthopyroxene is distinct in the elongated shape. Similar to the dunites, the harzburgites contain accessory amounts of clinopyroxene and amphibole with nearly equant morphology.

Samples collected as olivine-depleted bands during field investigations have $37 \mathrm{vol} \%-54 \mathrm{vol} \%$ olivine, $28 \mathrm{vol} \%-$ $51 \mathrm{vol} \%$ orthopyroxene and 5 vol \%-14 vol \% clinopyroxene. They are therefore classified as lherzolites and olivine websterites (Fig. 4a). For the sake of simplicity, they are hereafter referred to as lherzolites. Orthopyroxene and clinopyroxene mostly occur as nearly equant to subprismatic grains associated with polygonal olivine, thereby defining a nearly granoblastic structure with an average grain size of $1-2 \mathrm{~mm}$. Orthopyroxene also occurs as rare poikilitic grains (up $8 \mathrm{~mm}$ ) enclosing olivine and minor spinel, similar to the harzburgites. The lherzolite showing the highest clinopyroxene amounts locally comprises poikilitic clinopyroxene grains $(5-7 \mathrm{~mm})$ including sub-prismatic to rounded olivine, nearly equant minor spinel and, sporadically, subprismatic orthopyroxene (Fig. 5b). The lherzolites also contain accessory amounts of spinel and amphibole, which display nearly equant morphology.

In all peridotite samples, pyroxenes are exsolved (Fig. 5b). In particular, clinopyroxene exhibits a few micrometres thick exsolution lamellae of orthopyroxene and spinel. The outer regions of the clinopyroxene grains also locally include domains free of exsolution lamellae that contain minor amounts of globular amphibole (tens to hundreds of micrometres in size) and vermicular spinel (typically a few micrometres in thickness). Orthopyroxene has a few mi- 

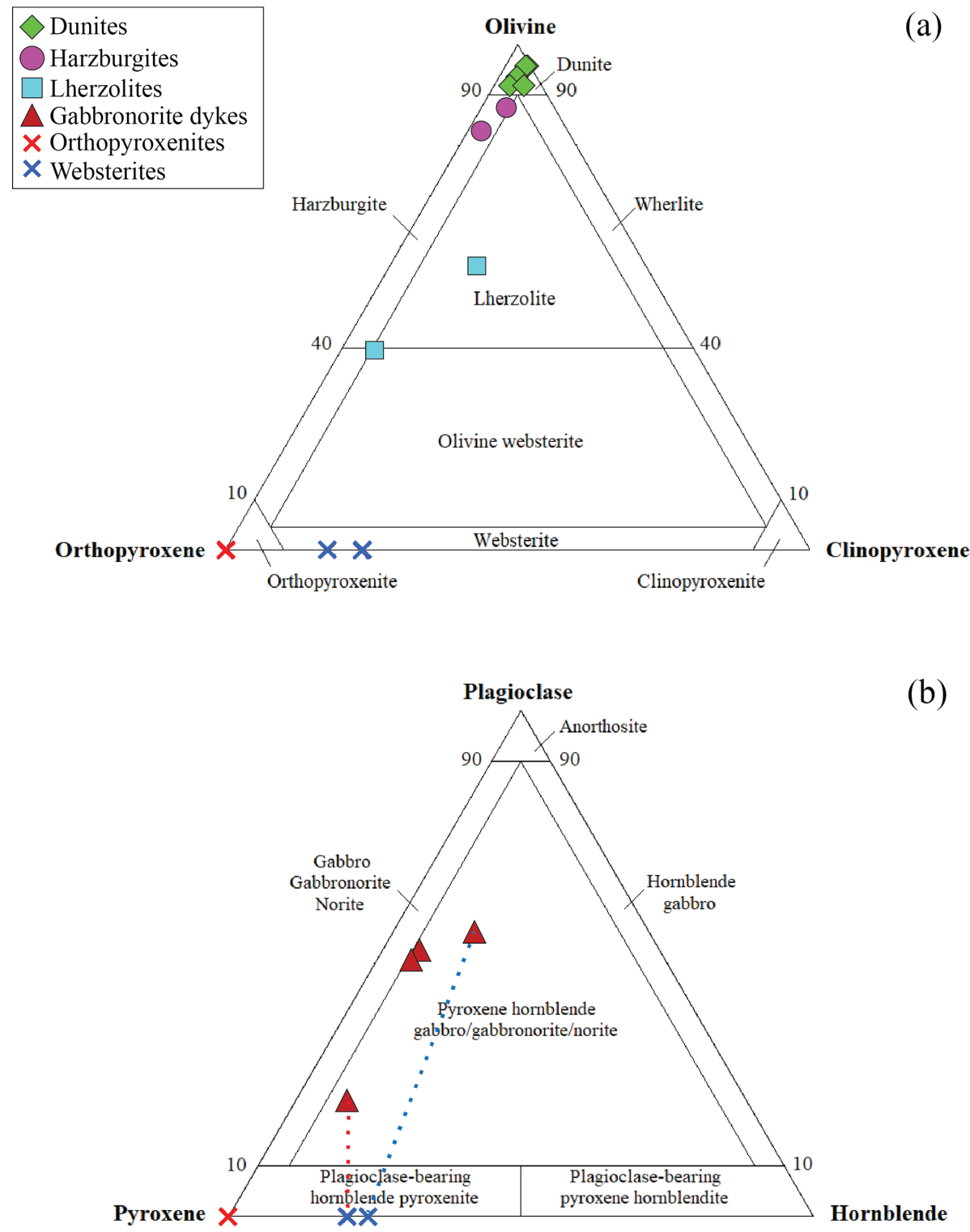

Figure 4. (a) Peridotite modal compositions (vol \%) reported in the olivine-orthopyroxene-clinopyroxene classification diagram of ultramafic rocks. The compositions of orthopyroxenite and websterite micro-layers formed along the contacts between the peridotites and crosscutting gabbronorite dykes are also reported. (b) Modal compositions of hornblende gabbronorite dykes (vol \%) reported in the plagioclasetotal pyroxene-amphibole classification diagram of gabbroic rocks. The compositions of orthopyroxenite and websterite micro-layers formed along the contacts between gabbronorite dykes and peridotites are also reported. The dotted tie lines refer to the gabbronites and physically adjacent websterite micro-layers (blue: sample BI2/5; red: sample BI10/3).

crometres thick lamellae of clinopyroxene and spinel. All selected samples include accessory amounts of $\mathrm{Fe}-\mathrm{Ni}-\mathrm{Cu}$ sulfides (pyrrhotite, pentlandite and minor chalcopyrite), which mostly occur along mineral grain boundaries, frequently in association with spinel. According to Bertolani and Loschi Ghittoni (1979), these sulfides are in places accompanied by cubanite and sphalerite.

\subsubsection{Whole-rock chemical compositions}

The peridotites show low loss on ignition values $(\leq 1.1 \mathrm{wt} \%)$, in agreement with the negligible low temperature alteration of selected samples. The Mg\# $\left[\mathrm{molarMg} /\left(\mathrm{Mg}+\mathrm{Fe}_{\text {tot }}^{2+}\right) \times 100\right]$ decreases from the dunites (87-90) to the harzburgites (86-87) and the lherzolites (8485). $\mathrm{Al}_{2} \mathrm{O}_{3}$ shows a rough negative correlation with $\mathrm{Mg} \#$ (Fig. 6). $\mathrm{CaO}$ is $0.6 \mathrm{wt} \%-1.2 \mathrm{wt} \%$ in the dunites and the harzburgites and $1.7 \mathrm{wt} \%-3.4 \mathrm{wt} \%$ in the lherzolites. Dunite 

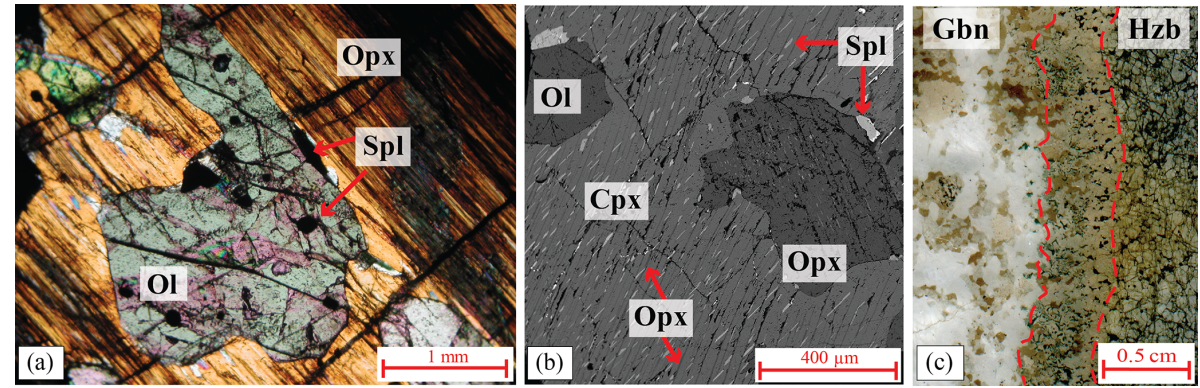

Figure 5. (a) Micro-photo showing a poikilitic orthopyroxene from harzburgite BI2/7 (crossed nicols). Olivine inclusions show embayed boundaries or rounded to elliptical shape. The largest olivine inclusion encloses several spinel grains with euhedral-subhedral morphology. Spinel with anhedral elongated morphology is present along the contact between olivine and enclosing orthopyroxene. Mineral abbreviations after Whitney and Evans (2010). (b) Back-scattered electron image showing a poikilitic clinopyroxene from lherzolite BI6/2. The clinopyroxene encloses olivine and orthopyroxene. In addition, spinel with elongated to nearly equant morphology is present along the contact between olivine-orthopyroxene and host clinopyroxene. The poikilitic clinopyroxene exhibits a few micrometres thick exsolution lamellae of orthopyroxene and spinel. The enclosed orthopyroxene is also exsolved, with a few micrometres thick lamellae of clinopyroxene and spinel. Mineral abbreviations after Whitney and Evans (2010). (c) Scanned thin section image showing the contact zone between harzburgite $\mathrm{BI} / 5(\mathrm{Hzb})$ and crosscutting gabbronorite dyke (Gbn). The contact zone is bounded by red dashed lines and consists of spinel-bearing orthopyroxenite towards the harzburgite and of spinel-bearing hornblende websterite towards the gabbronorite. The gabbronorite dyke shows granoblastic structure.

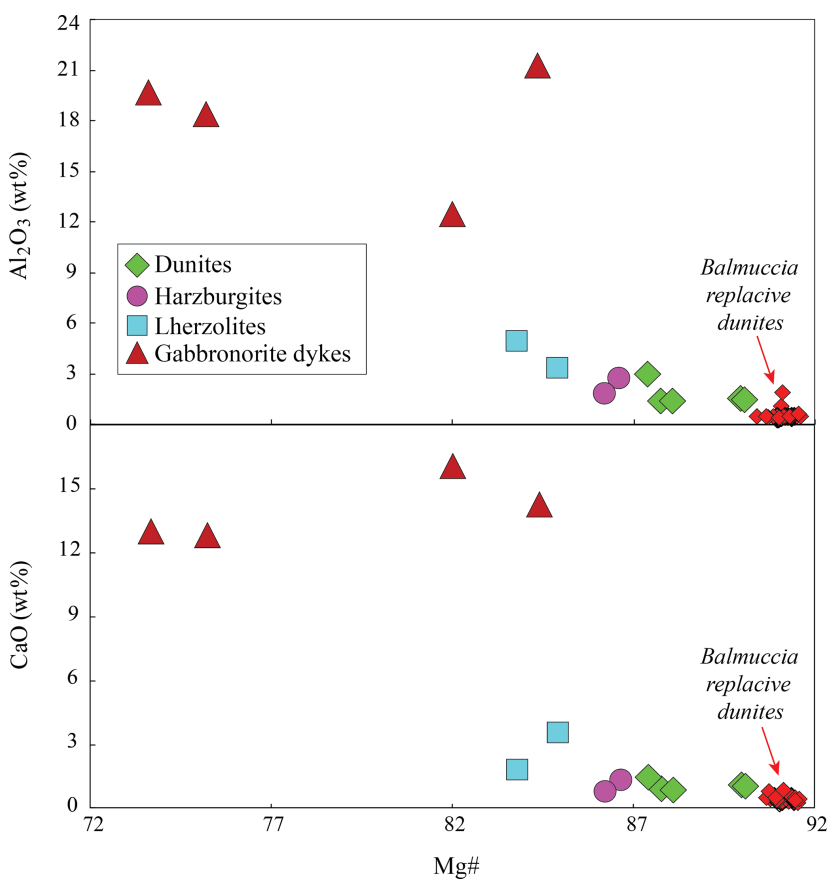

Figure 6. Diagrams showing the whole-rock chemical compositions of the selected samples from the Rocca d'Argimonia sequence. $\mathrm{Al}_{2} \mathrm{O}_{3}$ and $\mathrm{CaO}$, calculated on anhydrous basis, versus $\mathrm{Mg} \#\left[\mathrm{molarMg} /\left(\mathrm{Mg}+\mathrm{Fe}_{\text {tot }}^{2+}\right) \times 100\right]$. The compositions of mantle replacive dunites of the Balmuccia peridotite massif (Mazzucchelli et al., 2009) are reported for comparative purposes.

BI5/1 exhibits lower $\mathrm{SiO}_{2}$ and higher $\mathrm{Cr}_{2} \mathrm{O}_{3}$ (Table 1) than the other peridotites, in agreement with the relatively high spinel proportion observed for this sample (cf. Table 9).

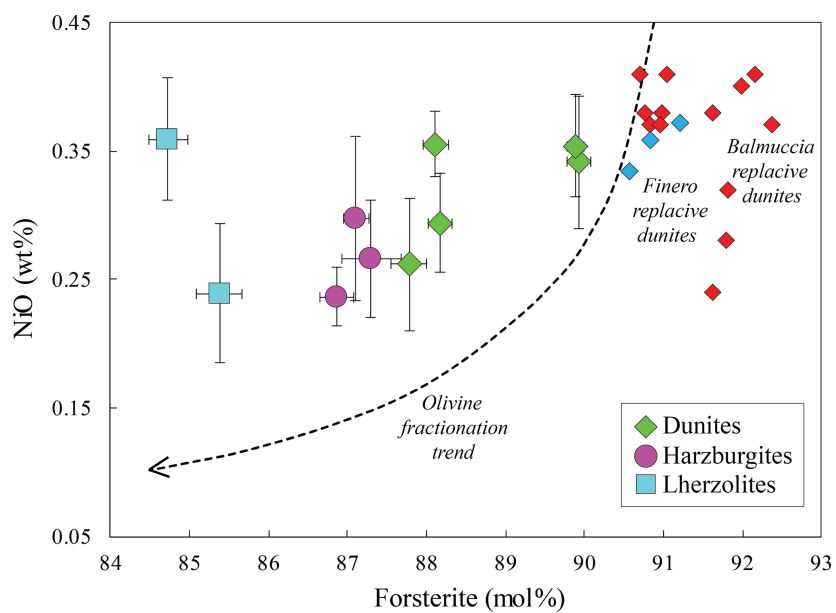

Figure 7. Plot of $\mathrm{NiO}(\mathrm{wt} \%$ ) versus forsterite proportion ( $\mathrm{mol} \%$ ) of olivine from the Rocca d'Argimonia peridotites. Data are averaged per sample; error bars represent the standard deviation of the mean value $(2 \sigma)$. The compositions of olivine from mantle replacive dunites of the Balmuccia and Finero mantle sequences (Mazzucchelli et al., 2009; Bussolesi et al., 2019; Corvò et al., 2020) are reported for comparative purposes. Olivine fractionation trend after Su et al. (2016).

\subsubsection{Mineral chemical compositions}

The peridotite minerals typically show minor intra-grain and within-sample chemical variability. The forsterite proportion of olivine (Fig. 7) decreases from the dunites $(90 \mathrm{~mol} \%$ $88 \mathrm{~mol} \%)$ to the harzburgites $(87 \mathrm{~mol} \%)$ and the lherzolites $(85 \mathrm{~mol} \%)$. In contrast, olivine $\mathrm{NiO}(0.24 \mathrm{wt} \%-0.36 \mathrm{wt} \%)$ shows no systematic variations among the different peridotite 


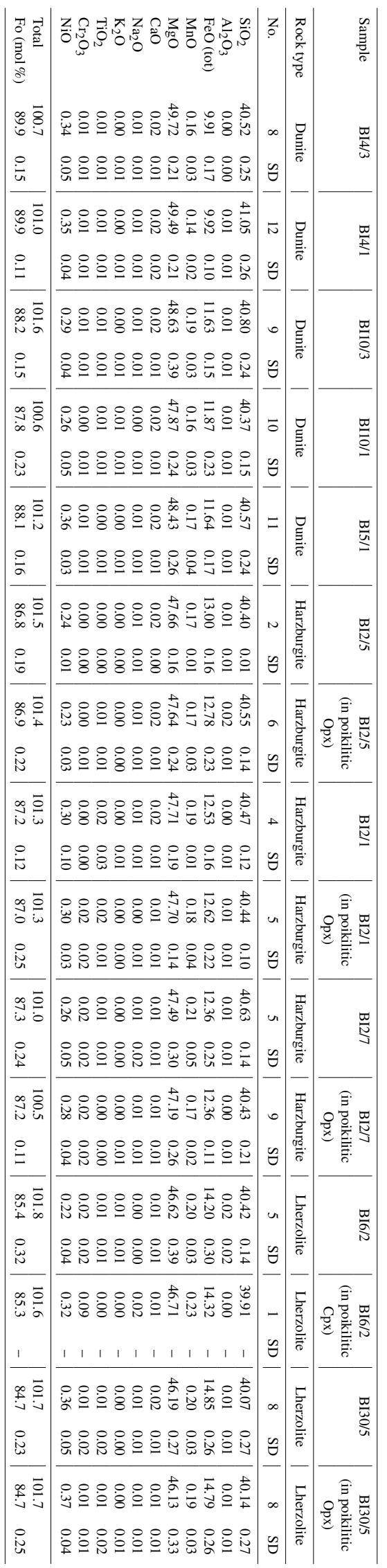

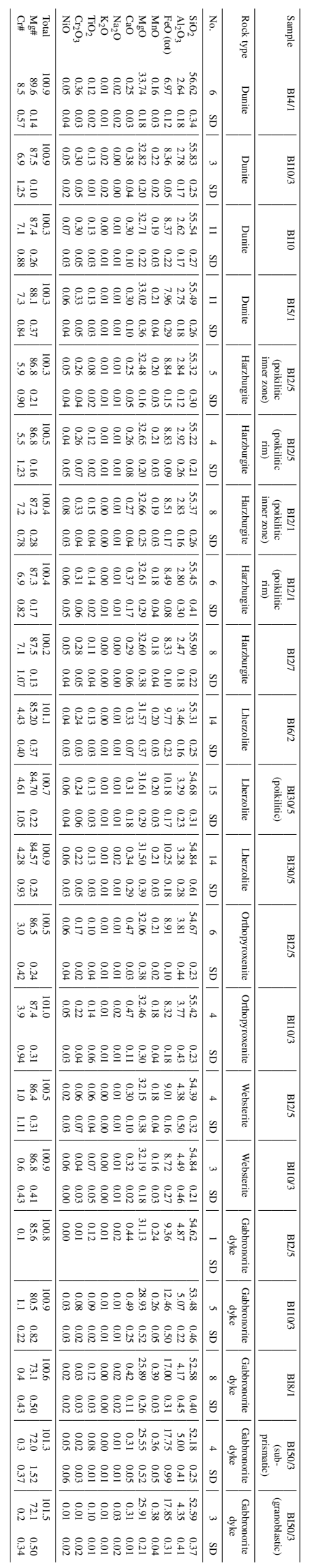

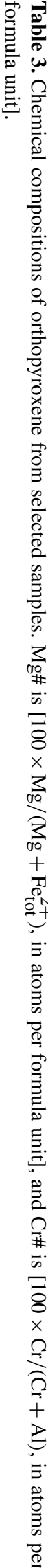

https://doi.org/10.5194/ejm-32-587-2020

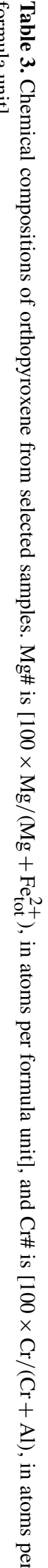

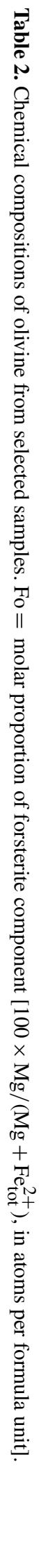

Eur. J. Mineral., 32, 587-612, 2020 


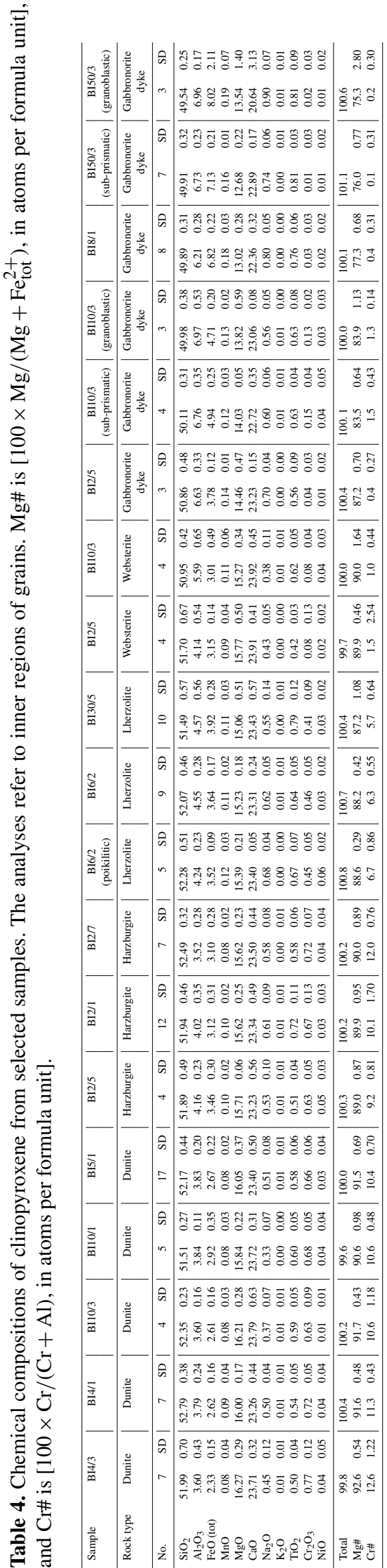

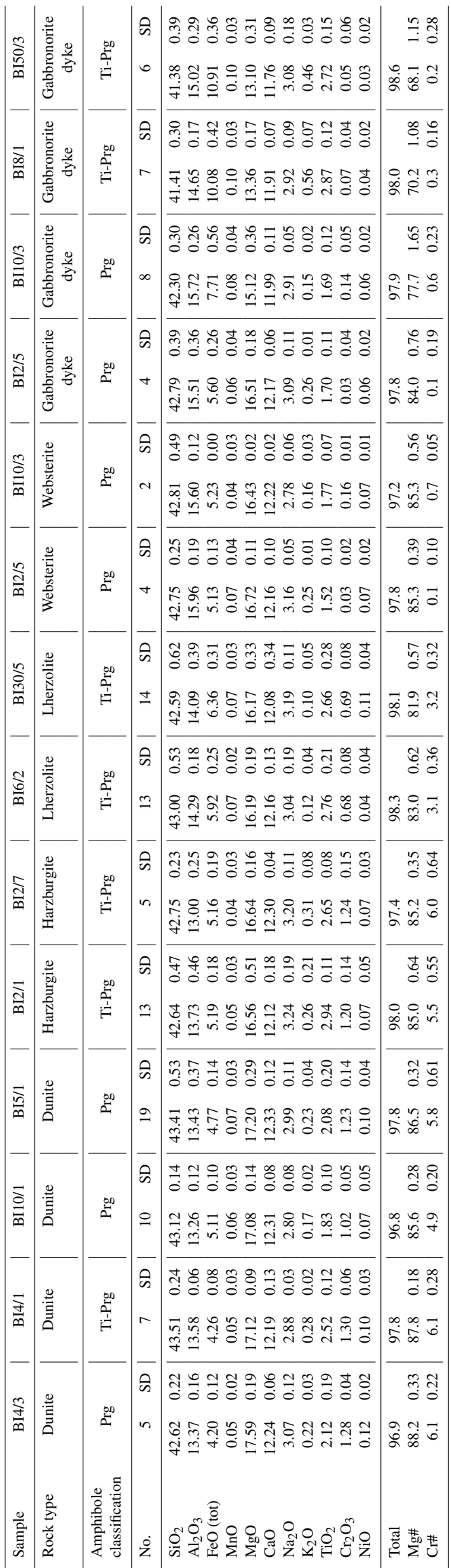




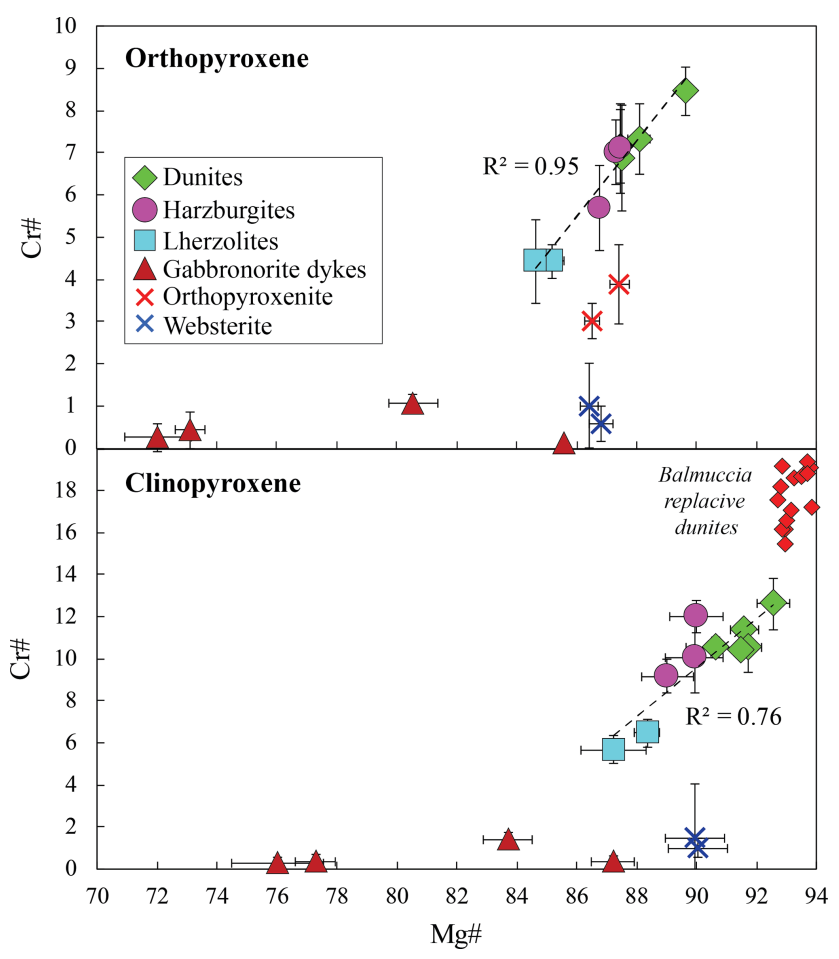

Figure 8. Plot of $\mathrm{Cr} \#[100 \times \mathrm{Cr} /(\mathrm{Cr}+\mathrm{Al})$, mol \%] versus $\mathrm{Mg} \#$ $\left[100 \times \mathrm{Mg} /\left(\mathrm{Mg}+\mathrm{Fe}_{\text {tot }}^{2+}\right)\right.$, mol \% $]$ of orthopyroxene and clinopyroxene from the selected samples of the Rocca d'Argimonia sequence. Data are averaged per sample; error bars represent the standard deviation of the mean value $(2 \sigma)$. The compositions of clinopyroxene from mantle replacive dunites of the Balmuccia peridotite massif (Mazzucchelli et al., 2009) are reported for comparative purposes.

types. In the harzburgites and the lherzolites, olivines within and external to poikilitic pyroxenes have similar compositions (Table 2).

The poikilitic orthopyroxene in the harzburgiteslherzolites show no significant chemical zoning (Table 3). Both orthopyroxene and clinopyroxene have Mg\# $\left[100 \times \mathrm{Mg} /\left(\mathrm{Mg}+\mathrm{Fe}_{\text {tot }}^{2+}\right)\right.$, mol \%] decreasing from the dunites to the harzburgites and the lherzolites and linearly correlating (Fig. 8) with $\mathrm{Cr} \#[100 \times \mathrm{Cr} /(\mathrm{Cr}+\mathrm{Al})$, mol \%]. Within a single lherzolite sample, pyroxenes showing different microstructures are chemically nearly homogeneous (see also Table 4). Overall, orthopyroxene contains $0.3 \mathrm{wt} \%-0.4 \mathrm{wt} \%$ $\mathrm{CaO}$, and clinopyroxene has $0.3 \mathrm{wt} \%-0.6 \mathrm{wt} \% \mathrm{Na}_{2} \mathrm{O}$ and 0.5 wt $\%-0.7$ wt $\% \mathrm{TiO}_{2}$.

According to the amphibole nomenclature of Leake et al. (1997), amphibole is pargasite to titanian pargasite in dunites and titanian pargasite in harzburgites and lherzolites (Table 5). Amphibole $\mathrm{Mg} \#$ and $\mathrm{Cr} \#$ roughly decrease from the dunites to the harzburgites and the lherzolites.

Spinels from the harzburgites and the dunites show overlapping Cr\# (16-31 and 20-28, respectively; Fig. 9). In the harzburgites, spinels within and external to poikilitic orthopyroxenes have similar compositions (Table 6). Spinel

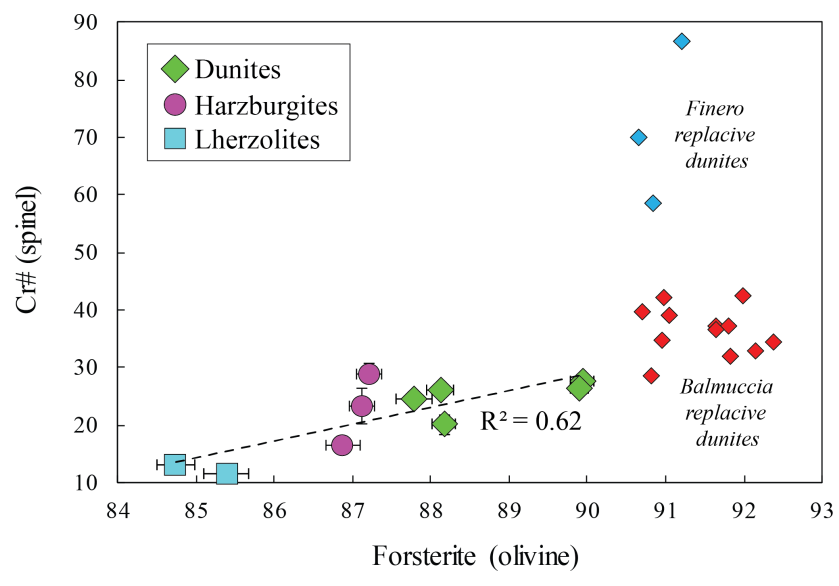

Figure 9. Plot of $\mathrm{Cr} \#[100 \times \mathrm{Cr} /(\mathrm{Cr}+\mathrm{Al})$, mol \%] of spinel versus forsterite proportion of coexisting olivine $(\mathrm{mol} \%)$ for the Rocca d'Argimonia peridotites. Data are averaged per sample; error bars represent the standard deviation of the mean value $(2 \sigma)$. The compositions of spinel-olivine pairs from mantle replacive dunites of the Balmuccia and Finero mantle sequences (Mazzucchelli et al., 2009; Bussolesi et al., 2019; Corvò et al., 2020) are reported for comparative purposes.

from the lherzolites is distinct in the low $\mathrm{Cr} \#$ of $\sim 11-$ 13. In all the peridotites, $\mathrm{TiO}_{2}$ in spinel is low $(0.03 \mathrm{wt} \%-$ $0.16 \mathrm{wt} \%)$. The spinel Cr\# yields a rough linear correlation when plotted against the forsterite proportion of coexisting olivine.

\subsubsection{Oxygen isotopic composition of olivine}

The ion microprobe analyses of olivine revealed limited $\delta^{18} \mathrm{O}$ variations within a single peridotite (Table 8). Olivine $\delta^{18} \mathrm{O}$ gradually increases with decreasing forsterite proportion (Fig. 10). In particular, the most primitive dunite and the most evolved lherzolite show $\delta^{18} \mathrm{O}_{\mathrm{Ol}}$ of $+5.77 \pm 0.10 \%$ (weighted average $\pm 2 \sigma, n=18$ ) and $+6.57 \pm 0.06 \%$ (weighted average $\pm 2 \sigma, n=20$ ), respectively. Taken as a whole, the Rocca d'Argimonia olivines have slightly higher $\delta^{18} \mathrm{O}$ than typical mantle olivines (5.2 $\pm 0.3 \%$, Mattey et al., 1994).

\subsection{Gabbronorite dykes and peridotite contact zones}

\subsubsection{Petrographic characteristics}

The gabbronorites mostly consist of plagioclase, clinopyroxene and orthopyroxene (Table 9) and display mediumgrained, granoblastic to nearly granoblastic structure (Fig. 5c). These rocks locally also include sub-prismatic grains of orthopyroxene and clinopyroxene, which in places enclose euhedral to subhedral plagioclase grains. The gabbronorites also show 6 vol \%-14 vol \% amphibole with nearly equant morphology and are classified as hornblende gabbronorites (Fig. 4b). Al spinel (Table 6) and $\mathrm{Fe}-\mathrm{Cu}$ sul- 


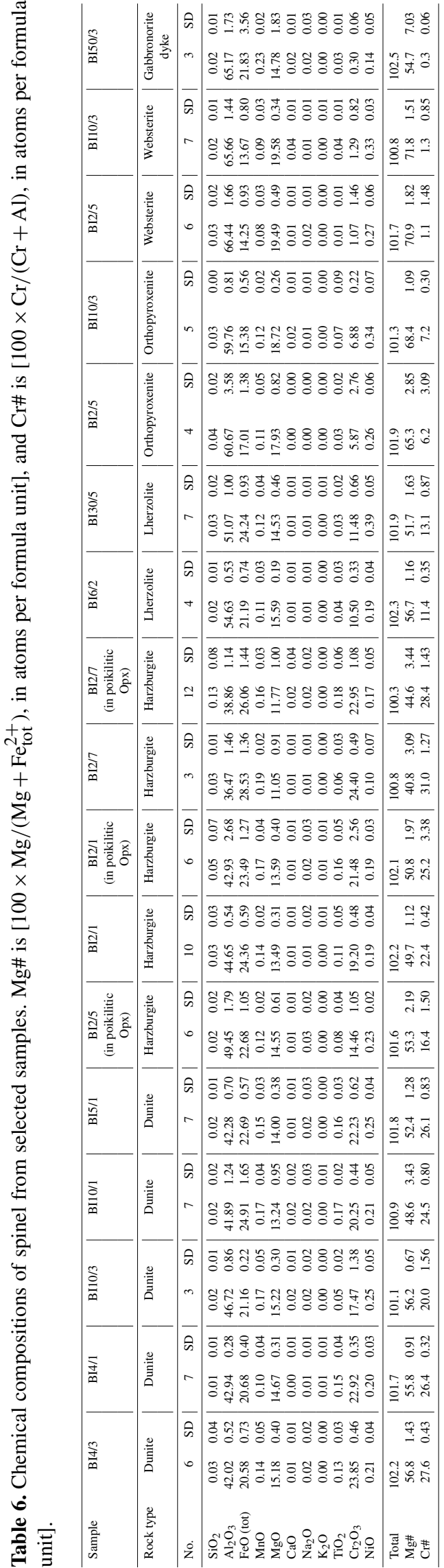

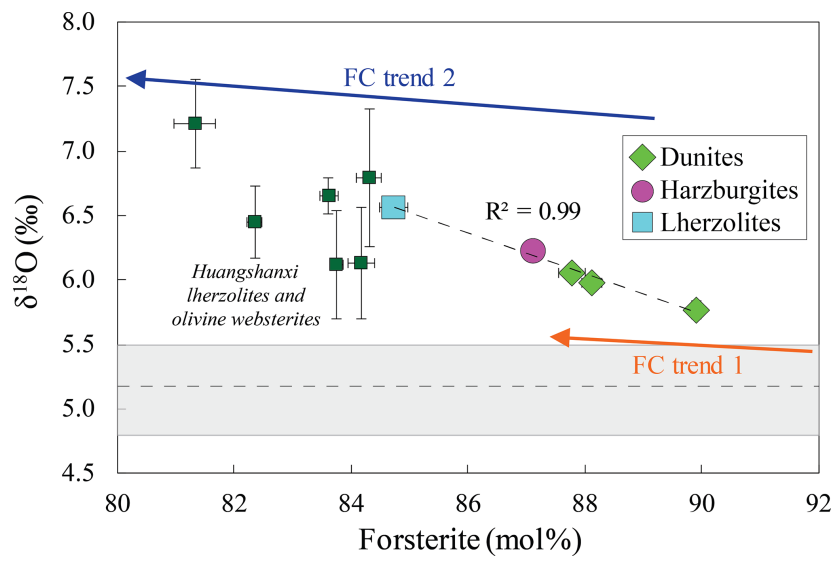

Figure 10. $\delta^{18} \mathrm{O}$ (weighted average $\pm 2 \sigma$ ) versus forsterite proportion (mean $\pm 2 \sigma$ ) of olivine from the Rocca d'Argimonia peridotites; the error bars are in most cases within the symbol area. The compositions of olivine from lherzolites and olivine websterites of the Huangshanxi mafic-ultramafic intrusion in northwestern China (Mao et al., 2019) are reported for comparative purposes. The grey field represents the $\delta^{18} \mathrm{O}$ of typical mantle olivines (Mattey et al., 1994). The diagram also reports the $\delta^{18} \mathrm{O}$ variations modelled by Bucholz et al. (2017) in response to closed system fractional crystallization for (i) an anhydrous tholeiite crystallizing at $1.0 \mathrm{GPa}$ (FC trend 1) and (ii) a high-K basalt with $2.5 \mathrm{H}_{2} \mathrm{O}$ crystallizing at $\sim 0.4 \mathrm{GPa}$ (FC trend 2). The anhydrous tholeiite model is based on the experimental results of Villiger et al. (2004); a typical mantle $\delta^{18} \mathrm{O}$ value of $+5.7 \%$ is assumed for the parental melt. Both models show that the $\delta^{18} \mathrm{O}_{\mathrm{Ol}}$ variations observed for the Rocca d'Argimonia peridotites are wider than those dictated by fractional crystallization alone.

fides (pyrrhotite and minor chalcopyrite) are common accessories.

The contact zone between gabbronorites and host peridotites was investigated for the thinnest selected dykes (samples BI2/5 and BI10/3, Table 10). In both cases, the contact zone consists of two different orthopyroxene-rich microlayers, each $\sim 2 \mathrm{~mm}$ thick (Fig. $5 \mathrm{c}$ ). Towards the peridotite side, there is a spinel-bearing orthopyroxenite with a nearly granoblastic structure defined by equant, polygonal morphology of orthopyroxene. This orthopyroxenite micro-layer in cludes 6 vol \%-9 vol \% spinel, which is typically anhedral and interstitial with respect to orthopyroxene. The microlayer adjacent to the gabbronorite is made up of orthopyroxene, amphibole, clinopyroxene and spinel, and it is therefore classified as hornblende websterite (Fig. 4). Pyroxenes and amphibole in the websterite micro-layer define a nearly granoblastic structure, whereas associated spinel has vermicular morphology. Accessory pyrrhotite occurs in both the orthopyroxenite and the hornblende websterite micro-layers. 
Table 7. Chemical compositions of plagioclase from selected samples. An $=$ molar proportion of anorthite component $[100 \times \mathrm{Ca} /(\mathrm{Ca}+\mathrm{K}+$ $\mathrm{Na})$, in atoms per formula unit].

\begin{tabular}{|c|c|c|c|c|c|c|c|c|c|c|}
\hline Sample & \multicolumn{2}{|c|}{$\mathrm{BI} 2 / 5$} & \multicolumn{2}{|c|}{ BI10/3 } & \multicolumn{2}{|c|}{ BI8/1 } & \multicolumn{2}{|c|}{$\begin{array}{c}\text { BI50/3 } \\
\text { (included in Px) }\end{array}$} & \multicolumn{2}{|c|}{$\begin{array}{c}\text { BI50/3 } \\
\text { (granoblastic) }\end{array}$} \\
\hline Rock type & $\begin{array}{r}\text { Gabbr } \\
\text { dy }\end{array}$ & orite & $\begin{array}{r}\text { Gabbr } \\
\text { dy }\end{array}$ & $\begin{array}{l}\text { horite } \\
\text { e }\end{array}$ & $\begin{array}{r}\text { Gabbr } \\
\text { dy }\end{array}$ & erite & $\begin{array}{r}\text { Gabb } \\
\mathrm{d}\end{array}$ & & $\begin{array}{r}\text { Gabbr } \\
\text { dy }\end{array}$ & \\
\hline No. & 9 & SD & 6 & SD & 8 & SD & 5 & SD & 5 & SD \\
\hline $\mathrm{SiO}_{2}$ & 47.47 & 0.31 & 46.00 & 0.31 & 49.36 & 0.27 & 48.85 & 0.60 & 49.52 & 0.12 \\
\hline $\mathrm{Al}_{2} \mathrm{O}_{3}$ & 33.55 & 0.48 & 34.46 & 0.11 & 32.32 & 0.27 & 33.62 & 0.30 & 33.04 & 0.31 \\
\hline $\mathrm{FeO}$ (tot) & 0.04 & 0.03 & 0.09 & 0.03 & 0.07 & 0.06 & 0.24 & 0.08 & 0.11 & 0.02 \\
\hline $\mathrm{MnO}$ & 0.01 & 0.01 & 0.01 & 0.02 & 0.01 & 0.02 & 0.00 & 0.00 & 0.01 & 0.02 \\
\hline $\mathrm{MgO}$ & 0.01 & 0.01 & 0.00 & 0.01 & 0.00 & 0.01 & 0.00 & 0.01 & 0.01 & 0.00 \\
\hline $\mathrm{CaO}$ & 16.58 & 0.33 & 17.82 & 0.28 & 15.52 & 0.14 & 16.17 & 0.53 & 15.54 & 0.12 \\
\hline $\mathrm{Na}_{2} \mathrm{O}$ & 2.08 & 0.20 & 1.35 & 0.13 & 2.90 & 0.13 & 2.59 & 0.30 & 2.88 & 0.13 \\
\hline $\mathrm{K}_{2} \mathrm{O}$ & 0.01 & 0.01 & 0.01 & 0.01 & 0.02 & 0.01 & 0.01 & 0.01 & 0.02 & 0.00 \\
\hline $\mathrm{TiO}_{2}$ & 0.00 & 0.00 & 0.02 & 0.04 & 0.01 & 0.02 & 0.02 & 0.03 & 0.00 & 0.01 \\
\hline $\mathrm{Cr}_{2} \mathrm{O}_{3}$ & 0.02 & 0.02 & 0.02 & 0.03 & 0.01 & 0.01 & 0.03 & 0.03 & 0.03 & 0.03 \\
\hline $\mathrm{NiO}$ & 0.01 & 0.02 & 0.00 & 0.00 & 0.02 & 0.02 & 0.02 & 0.03 & 0.03 & 0.05 \\
\hline Total & 99.8 & & 99.8 & & 100.2 & & 101.6 & & 101.2 & \\
\hline An $(\mathrm{mol} \%)$ & 81.5 & 1.75 & 87.9 & 1.19 & 74.7 & 0.97 & 77.5 & 2.54 & 74.8 & 0.96 \\
\hline
\end{tabular}

\subsubsection{Whole-rock chemical compositions}

The thin dykes BI2/5 and BI10/3 have higher Mg\# than the thick dykes $\mathrm{BI} 8 / 1$ and $\mathrm{BI} 50 / 3$ (82-84 and 74-75, respectively). Taken as a whole, the gabbronorites have high $\mathrm{Al}_{2} \mathrm{O}_{3}$ and $\mathrm{CaO}$ contents (Fig. 6), which are mostly controlled by the high modal proportions of plagioclase and clinopyroxene, respectively. In particular, the gabbronorite BI10/3 has the lowest $\mathrm{Al}_{2} \mathrm{O}_{3}$ and the highest $\mathrm{CaO}$ reflecting its low plagioclase / clinopyroxene modal ratio (cf. Tables 1 and 9).

\subsubsection{Mineral chemical compositions}

The minerals constituting the gabbronorite dykes are compositionally homogeneous within a single sample. Taken as a whole, however, clinopyroxene, orthopyroxene and amphibole (pargasite to titanian pargasite) from the gabbronorites show wide Mg\# variations (Fig. 8, Tables 3, 4 and 5) paralleling the whole-rock variations. $\mathrm{Cr}_{2} \mathrm{O}_{3}$ in mafic silicates from the gabbronorites is invariably negligible $(\leq 0.1 \mathrm{wt} \%)$. Orthopyroxene contains $0.3 \mathrm{wt} \%-0.5 \mathrm{wt} \% \mathrm{CaO}$, and clinopyroxene displays $0.6 \mathrm{wt} \%-0.8 \mathrm{wt} \% \quad \mathrm{Na}_{2} \mathrm{O}$ and $0.6 \mathrm{wt} \%-$ $0.8 \mathrm{wt} \% \mathrm{TiO}_{2}$. Plagioclase from the gabbronorites has anorthite proportion ranging from $88 \mathrm{~mol} \%$ to $75 \mathrm{~mol} \%$ (Table 7).

In the gabbronorite-peridotite contact zone, orthopyrox-

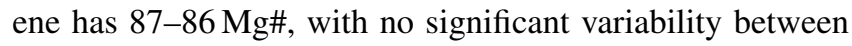
the websterite and the orthopyroxenite micro-layer (Fig. 8). Conversely, orthopyroxene shows a $\mathrm{Cr}_{2} \mathrm{O}_{3}$ decrease and a concomitant $\mathrm{Al}_{2} \mathrm{O}_{3}$ increase (i.e. a Cr\# decrease) from the orthopyroxenite to the websterite micro-layer, which is par-

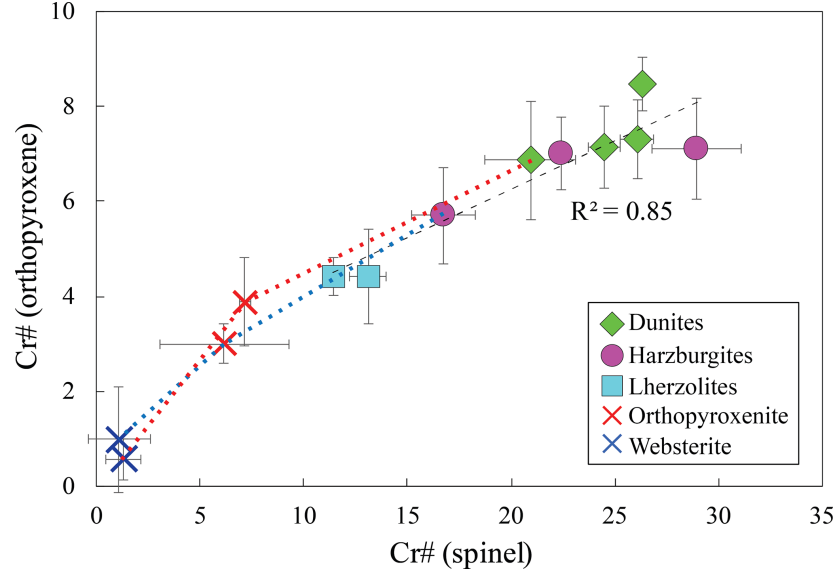

Figure 11. Plot of $\mathrm{Cr} \#[100 \times \mathrm{Cr} /(\mathrm{Cr}+\mathrm{Al})$, mol \%] of orthopyroxene versus $\mathrm{Cr} \#$ of coexisting spinel $(\mathrm{mol} \%)$ for the Rocca d'Argimonia peridotites. Data are averaged per sample; error bars represent the standard deviation of the mean value $(2 \sigma)$. The diagram also reports the compositions of orthopyroxene-spinel pairs from the contact zone at the boundaries between the thin gabbronorite BI2/5 and BI10/3 dykes and host peridotites. The dotted tie lines refer to these contact zones and physically adjacent peridotites (blue: sample BI2/5; red: sample BI10/3).

alleled by associated spinel (Fig. 11). Clinopyroxene and amphibole (pargasite) present in the websterite micro-layer exhibit high $\mathrm{Mg} \#$ of 90 and 85, respectively. 


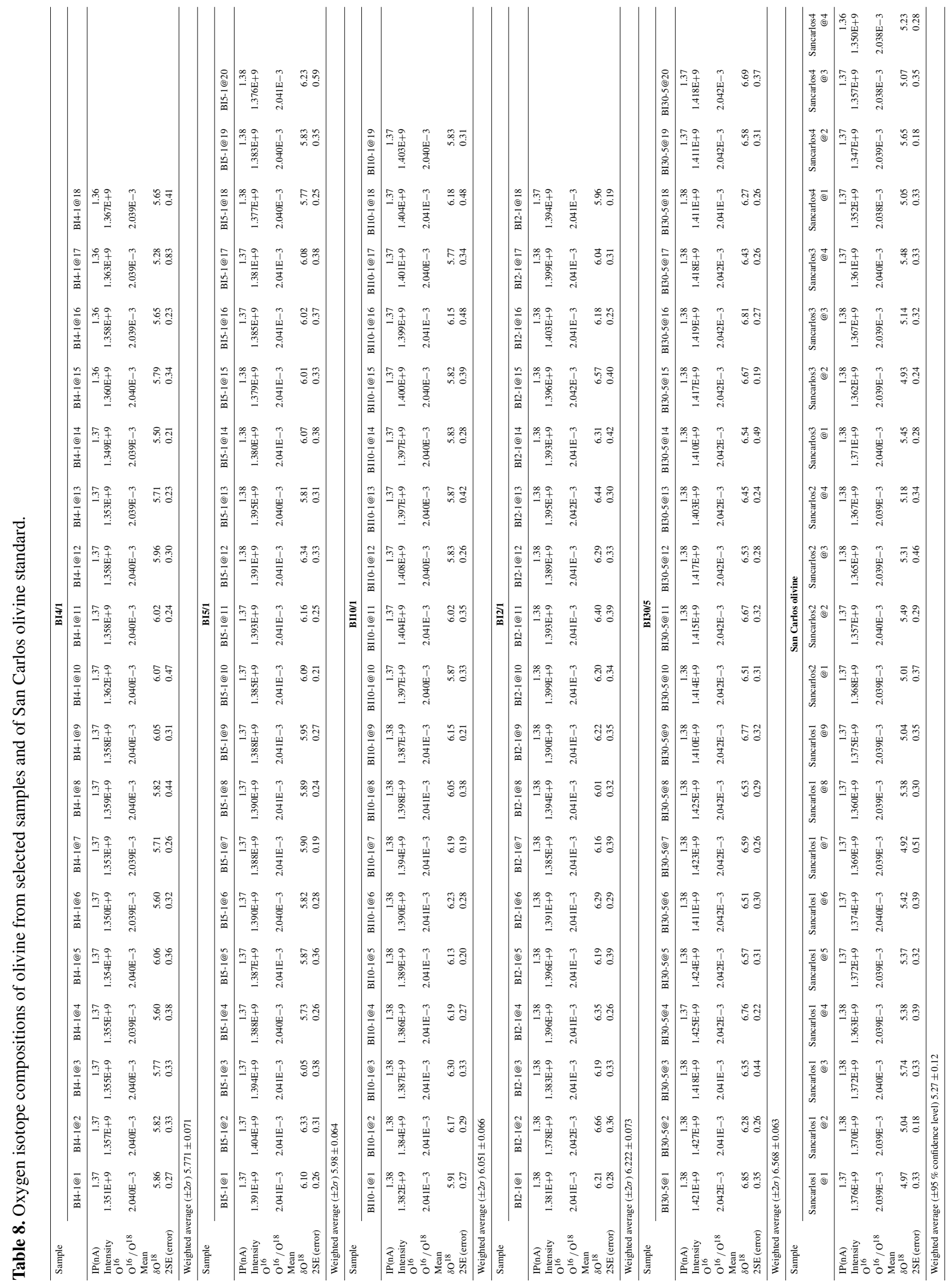


Table 9. Location and main petrographic characteristics of selected samples. Mineral proportion calculations (wt \%) were carried out on anhydrous basis, assuming all $\mathrm{Fe}$ as $\mathrm{Fe}^{2+}$. We used a least squares mixing programme to reproduce the observed whole-rock compositions (Table 1) based on mineral compositions (Tables 2-7). For the peridotites, the best fit between observed and calculated whole-rock compositions was obtained by refinements based on the following: (i) $\mathrm{TiO}_{2}, \mathrm{CaO}$ and $\mathrm{Na}_{2} \mathrm{O}$ for clinopyroxene and amphibole proportions and (ii) $\mathrm{SiO}_{2}, \mathrm{Al}_{2} \mathrm{O}_{3}, \mathrm{NiO}$ and $\mathrm{Cr}_{2} \mathrm{O}_{3}$ for olivine, orthopyroxene and spinel proportions. Obtained weight proportions were converted to volume proportions based on mineral densities (olivine $=3.3-3.4 \mathrm{~g} \mathrm{~cm}^{-3}$, orthopyroxene $=3.3-3.4 \mathrm{~g} \mathrm{~cm}^{-3}$, clinopyroxene $=3.2-3.3 \mathrm{~g} \mathrm{~cm}^{-3}$, amphibole $=3.2 \mathrm{~g} \mathrm{~cm}^{-3}$, spinel $=4.0-4.4 \mathrm{~g} \mathrm{~cm}^{-3}$ and plagioclase $\left.=2.7 \mathrm{~g} \mathrm{~cm}^{-3}\right)$. Mineral abbreviations are after Whitney and Evans $(2010)$, and rock nomenclature follows the classification of the International Union of Geological Sciences.

\begin{tabular}{|c|c|c|c|c|c|c|c|c|c|c|c|c|c|c|c|c|c|c|c|c|c|c|c|c|}
\hline \multirow[b]{2}{*}{$\begin{array}{l}\text { Sample } \\
\text { initials }\end{array}$} & \multicolumn{6}{|c|}{ Mineral modes (wt \%) } & \multicolumn{6}{|c|}{ Mineral modes (vol \%) } & \multicolumn{6}{|c|}{ Average grain size $(\mathrm{mm})$} & \multicolumn{3}{|c|}{ Notes } & \multirow{2}{*}{$\begin{array}{l}\text { Rock } \\
\text { nomenclature }\end{array}$} & \multicolumn{2}{|c|}{ Coordinates } \\
\hline & $\mathrm{O} 1$ & Opx & Cpx & Amp & $\mathrm{Pl}$ & Spl & Ol & Opx & Cpx & Amp & $\mathrm{Pl}$ & Spl & $\mathrm{Ol}$ & Opx & Cpx & Amp & $\mathrm{Pl}$ & Spl & $\begin{array}{r}\text { Dyke } \\
\text { width }(\mathrm{cm})\end{array}$ & $\begin{array}{l}\text { Host } \\
\text { rock }\end{array}$ & Other notes & & $\mathrm{x}$ & $\mathrm{y}$ \\
\hline Dunite BI4/3 & 92.1 & 0.6 & 3.3 & 1.2 & - & 2.8 & 92 & 1 & 3 & 1 & - & 2 & 3.0 & 0.3 & 0.7 & 0.5 & - & 0.6 & & & & $\begin{array}{l}\text { Hornblende- } \\
\text { bearing dunite }\end{array}$ & 430064.0 & 5057698.8 \\
\hline DuniteBI4/1 & 92.1 & 0.6 & 3.4 & 1.1 & - & 2.8 & 92 & 1 & 4 & 1 & - & 2 & 2.5 & 1.0 & 1.0 & 0.6 & - & 0.7 & & & & $\begin{array}{l}\text { Hornblende- } \\
\text { bearing dunite }\end{array}$ & 430059.0 & 5057692.9 \\
\hline Dunite BI10/3 & 88.5 & 5.3 & 2.5 & 1.2 & - & 2.5 & 89 & 5 & 3 & 1 & - & 2 & 3.0 & 1.0 & 1.0 & up to 0.6 & - & 0.7 & & & & $\begin{array}{l}\text { Hornblende- } \\
\text { bearing dunite }\end{array}$ & 429924.6 & 5057549.3 \\
\hline Dunite BI10/1 & 90.8 & 2.8 & 2.8 & 1.1 & - & 2.5 & 91 & 3 & 3 & 1 & - & 2 & 2.0 & 2.0 & 1.5 & 0.6 & - & 0.7 & & & & $\begin{array}{l}\text { Hornblende- } \\
\text { bearing dunite }\end{array}$ & 429912.2 & 5057561.7 \\
\hline Dunite BI5/1 & 84.8 & 2.8 & 4.8 & 1.9 & - & 5.7 & 85 & 3 & 5 & 2 & - & 5 & 3.0 & 3.0 & 1.5 & 0.5 & - & 0.8 & & & $\begin{array}{l}\text { Large non- } \\
\text { poikilitic Opx }\end{array}$ & $\begin{array}{l}\text { Hornblende- } \\
\text { bearing dunite }\end{array}$ & 430205.7 & 5057811.1 \\
\hline $\begin{array}{l}\text { Harzburgite } \\
\mathrm{B} 2 / 1\end{array}$ & 83 & 7.2 & 4.2 & 1.5 & - & 4.1 & 83 & 7 & 4 & 2 & - & 3 & 1.5 & 9.0 & 1.0 & 0.6 & - & 0.6 & & & $\begin{array}{l}\text { Poikilitic Opx } \\
\text { (up to } 1 \mathrm{~cm} \text { ) }\end{array}$ & $\begin{array}{l}\text { Hornblende- } \\
\text { bearing }\end{array}$ & 429923.3 & 5057732.4 \\
\hline $\begin{array}{l}\text { Harzburgite } \\
\text { BI } 2 / 7\end{array}$ & 79.5 & 14.1 & 2.2 & 0.9 & - & 3.3 & 79 & 15 & 2 & 1 & - & 3 & 1.7 & 8.0 & 0.7 & 0.5 & - & 0.5 & & & $\begin{array}{l}\text { Poikilitic Opx } \\
\text { (up to } 1 \mathrm{~cm} \text { ) }\end{array}$ & $\begin{array}{l}\text { Hornblende- } \\
\text { bearing } \\
\text { harzburgite }\end{array}$ & 429861.8 & 5057726.5 \\
\hline $\begin{array}{l}\text { Lherzolite } \\
\text { BI6/2 }\end{array}$ & 54.3 & 27.2 & 13.8 & 1.7 & - & 3 & 54 & 28 & 14 & 2 & - & 3 & 1.0 & 1.5 & $2.0^{*}$ & up to 0.6 & - & 0.6 & & & $\begin{array}{l}\text { Poikilitic Cpx } \\
(0.6 \mathrm{~cm})\end{array}$ & $\begin{array}{l}\text { Hornblende- } \\
\text { bearing lherzo- } \\
\text { lite }\end{array}$ & 429925.1 & 5057663.0 \\
\hline $\begin{array}{l}\text { Lherzolite } \\
\text { BI30/5 }\end{array}$ & 37.6 & 50.3 & 5.3 & 2.3 & - & 4.5 & 37 & 51 & 5 & 2 & - & 4 & 1.0 & $2.0^{*}$ & 1.5 & 0.6 & - & 0.7 & & & $\begin{array}{l}\text { Poikilitic Opx } \\
\text { (up to } 0.8 \mathrm{~cm} \text { ) }\end{array}$ & $\begin{array}{l}\text { Hornblende- } \\
\text { bearing olivine } \\
\text { websterite }\end{array}$ & 429768.9 & 5057796.4 \\
\hline $\begin{array}{l}\text { Gabbronorite } \\
\text { dyke BI2/5 }\end{array}$ & - & 17.8 & 14.8 & 15.1 & 51.3 & 1.0 & - & 16 & 13 & 14 & 56 & 1 & - & 1.0 & 1.0 & 1.0 & 2.0 & 0.3 & 2.5 & $\begin{array}{l}\text { Harzburg- } \\
\text { ite }\end{array}$ & & $\begin{array}{l}\text { Hornblende } \\
\text { gabbronorite }\end{array}$ & 429902.3 & 5057750.2 \\
\hline $\begin{array}{l}\text { Gabbronorite } \\
\text { dyke BII0/3 }\end{array}$ & - & 22.8 & 47.8 & 9.3 & 19.3 & 0.8 & - & 22 & 46 & 9 & 22 & 1 & - & 5.0 & 5.0 & 1.0 & 2.0 & 0.5 & 3.0 & Dunite & & $\begin{array}{l}\text { Hornblende } \\
\text { gabbronorite }\end{array}$ & 429924.6 & 5057549.3 \\
\hline $\begin{array}{l}\text { Gabbronorite } \\
\text { dyke BI } 8 / 1\end{array}$ & - & 23.9 & 21.6 & 7.0 & 47.5 & & - & 21 & 20 & 7 & 53 & - & - & 1.0 & 1.0 & 1.0 & 1.5 & - & 10.0 & $\begin{array}{l}\text { Harzburg- } \\
\text { ite }\end{array}$ & $\begin{array}{l}\text { Sparse sub-prismatic } \\
\text { Px, up to } 3.5 \mathrm{~mm} \text { long }\end{array}$ & $\begin{array}{l}\text { Hornblende } \\
\text { gabbronorite }\end{array}$ & 429849.7 & 5057694.9 \\
\hline $\begin{array}{l}\text { Gabbronorite } \\
\text { dyke BI50/3 }\end{array}$ & - & 23.0 & 24.3 & 6.0 & 44.9 & 1.8 & - & 20 & 22 & 6 & 50 & 1 & - & 3.0 & 3.0 & 1.0 & 1.7 & 1.0 & 25.0 & $\begin{array}{l}\text { Harzburg- } \\
\text { ite }\end{array}$ & $\begin{array}{l}\text { Frequent sub-prismatic } \\
\text { Px, up to } 7 \mathrm{~mm} \text { long }\end{array}$ & $\begin{array}{l}\text { Hornblende } \\
\text { gabbronorite }\end{array}$ & 429431.9 & 5056741.6 \\
\hline
\end{tabular}

* Poikilitic grains are not considered in the average grain size.

Table 10. Main petrographic characteristics of micro-layers occurring along the contacts between gabbronorite dykes and host peridotites. Mineral proportions were evaluated by point counting. Mineral abbreviations are after Whitney and Evans (2010), and rock nomenclature follows the classification of the International Union of Geological Sciences.

\begin{tabular}{|c|c|c|c|c|c|c|c|c|c|c|}
\hline \multirow{2}{*}{ Sample initials } & \multirow{2}{*}{$\begin{array}{r}\text { Average } \\
\text { thickness } \\
(\mathrm{mm})\end{array}$} & \multicolumn{4}{|c|}{ Mineral modes (vol \%) } & \multicolumn{4}{|c|}{ Average grain size $(\mathrm{mm})$} & \multirow{2}{*}{ Rock nomenclature } \\
\hline & & Opx & Cpx & Amp & Spl & Opx & Spl & Amp & Cpx & \\
\hline BI2/5 towards peridotite & 2.0 & 93.7 & - & - & 6.3 & \multirow{2}{*}{0.6} & \multirow{2}{*}{0.4} & \multirow{2}{*}{-} & \multirow{2}{*}{-} & Orthopyroxenite \\
\hline BI10/3 towards peridotite & 1.9 & 91.4 & - & - & 8.6 & & & & & Orthopyroxenite \\
\hline BI2/5 towards gabbronorite & 2.5 & 57.7 & 12.2 & 22 & 8.1 & \multirow{2}{*}{0.4} & \multirow{2}{*}{0.3} & \multirow{2}{*}{0.4} & \multirow{2}{*}{0.4} & Hornblende websterite \\
\hline BI10/3 towards gabbronorite & 2.6 & 53.9 & 16.4 & 17.9 & 11.8 & & & & & Hornblende websterite \\
\hline
\end{tabular}

\section{Discussion}

\subsection{The Rocca d'Argimonia rock sequence: effects of subsolidus re-equilibration}

The Rocca d'Argimonia ultramafic sequence shows alternating peridotite and pyroxenite layers that are tens of metres in thickness (Fig. 2; see also Lensch, 1968) and is locally crosscut by gabbronorite dykes. The Rocca d'Argimonia rocks, including the gabbronorite dykes, typically display both nearly granoblastic structure documenting re-equilibration by solid-state diffusion and/or recrystallization and relics of microstructures that may be reconciled with magmatic processes. The latter include the poikilitic morphology of orthopyroxene (Figs. 3a and 5a) in the harzburgites and the lherzolites and of clinopyroxene in the lherzolites (Fig. 5b). Evidence for a magmatic growth in the dunites is furnished by the orthopyroxene typically exhibiting anhedral habit, locally interstitial with respect to olivine, and by the euhedral to subhedral morphology of spinel grains enclosed by olivine. The gabbronorites retain magmatic structures at the macroscopic scale, as shown by the modal-grain size layer- 
Table 11. Temperature estimates $\left({ }^{\circ} \mathrm{C}\right)$ obtained for the selected rocks of the Rocca d'Argimonia sequence. A confining pressure of $0.8 \mathrm{GPa}$ was assumed in the calculations, in agreement with pressure estimates reported by Demarchi et al. (1998) for the base of the Ivrea Mafic Complex. The method of Putirka (2016) was applied using Eq. (6).

\begin{tabular}{|c|c|c|c|c|c|c|c|c|c|c|c|c|c|c|c|}
\hline Sample & BI4/1 & BI10/3 & BI10/1 & $\mathrm{BI} 5 / 1$ & $\mathrm{BI} 2 / 5$ & $\mathrm{BI} 2 / 1$ & $\mathrm{BI} 2 / 7$ & $\mathrm{BI} 6 / 2$ & $\mathrm{BI} 30 / 5$ & $\mathrm{BI} 2 / 5$ & BI10/3 & $\mathrm{BI} 2 / 5$ & BI10/3 & $\mathrm{BI} / 1$ & $\mathrm{BI} 50 / 3$ \\
\hline Rock type & \multicolumn{4}{|c|}{ Dunites } & \multicolumn{3}{|c|}{ Harzburgites } & \multicolumn{2}{|c|}{ Lherzolites } & \multicolumn{2}{|c|}{ Websterites } & \multicolumn{4}{|c|}{ Gabbronorite dykes } \\
\hline $\begin{array}{l}\text { Brey and Kohler } \\
\text { (1990) } \\
\text { Ca-in-Opx }\end{array}$ & 751 & 811 & 751 & 743 & 749 & 758 & 752 & 753 & 753 & - & - & - & - & - & - \\
\hline $\begin{array}{l}\text { Brey and Kohler } \\
\text { (1990) } \\
\text { Cpx-Opx }\end{array}$ & 810 & 736 & 719 & 788 & 780 & 771 & 708 & 765 & 747 & - & - & - & - & - & - \\
\hline $\begin{array}{l}\text { Wells (1977) } \\
\text { Cpx-Opx }\end{array}$ & 858 & 833 & 816 & 838 & 847 & 817 & 804 & 818 & 804 & 778 & 793 & 810 & 838 & 810 & 830 \\
\hline $\begin{array}{l}\text { Holland and } \\
\text { Blundy (1994) } \\
\text { Amp-Pl }\end{array}$ & - & - & - & - & - & - & - & - & - & - & - & 971 & 1035 & 979 & 996 \\
\hline $\begin{array}{l}\text { Putirka (2016) } \\
\text { Amp }\end{array}$ & - & - & - & - & - & - & - & - & - & - & - & 1030 & 1008 & 1008 & 999 \\
\hline
\end{tabular}

ing and the pyroxenes oriented orthogonally with respect to dyke walls, and at microscopic scale, with the local occurrence of sub-prismatic pyroxene grains hosting euhedral to subhedral plagioclase.

Application of the Ca-in-orthopyroxene and the orthopyroxene-clinopyroxene geothermometers of Brey and Kohler (1990) to the peridotites gave subsolidus estimates of $708-810^{\circ} \mathrm{C}$ (Table 11 ). We also employed the two-pyroxene geothermometer of Wells (1977), which does not require the presence of olivine and spinel in the confining mineral assemblage, obtaining $804-858^{\circ} \mathrm{C}$ for the peridotites and $810-838^{\circ} \mathrm{C}$ for the gabbronorites. The Wells' (1977) method yielded similar temperature values of $778-793{ }^{\circ} \mathrm{C}$ for the websterite micro-layer occurring along the gabbronoriteperidotite contact. Overall, these temperature evaluations correspond to granulite facies metamorphic conditions and most likely reflect slow cooling of the Rocca d'Argimonia sequence in the lower continental crust. On the other hand, application of the amphibole-plagioclase geothermometer of Holland and Blundy (1994) to the gabbronorite dykes gave relatively high temperature values of $971-1035^{\circ} \mathrm{C}$. For the gabbronorites, we obtained similar estimates of 999- $1030^{\circ} \mathrm{C}$ based on the single amphibole geothermometer of Putirka (2016). Most likely, the amphibole-based geothermometers have a higher closure temperature than the pyroxene-based methods. The amphibole-based temperature evaluations could refer to late magmatic conditions, in agreement with the temperature range observed in fractional crystallization experiments from hydrous melts carried out at 0.7-0.9 GPa (e.g. Nekvasil et al., 2004).

The re-equilibration shown by the two-pyroxene geothermometry may have affected the original oxygen isotope mineral distribution through diffusive exchange (Giletti, 1986; Eiler et al., 1992, 1993; Valley, 2001). In particular, the slow cooling potentially produces a slight $\delta^{18} \mathrm{O}$ olivine de- crease and a concomitant $\delta^{18} \mathrm{O}$ increase of coexisting pyroxene (Chiba et al., 1989; Rosenbaum et al., 1994). If an olivine crystallized from a melt at $1300^{\circ} \mathrm{C}$ and subsequently completely re-equilibrated with pyroxene at $700^{\circ} \mathrm{C}$, the $\delta^{18} \mathrm{O}_{\mathrm{Ol}}$ is expected to lower by $0.4 \%$. The primary $\delta^{18} \mathrm{O}_{\mathrm{Ol}}$ of the Rocca d'Argimonia peridotites could therefore be slightly higher than the observed value. It should be noted, however, that olivine is characterized by a low oxygen self-diffusivity (Dohmen et al., 2002). Actually, in mafic-ultramafic intrusions from middle and upper crustal levels, olivine is typically considered to retain the magmatic oxygen isotopic signature (e.g. Bucholz et al., 2017; Günther et al., 2018; Mao et al., 2019). Preservation of magmatic $\delta^{18} \mathrm{O}_{\mathrm{Ol}}$ in the Rocca d'Argimonia peridotites could be favoured by the relatively large crystal size of olivine (1-3 mm in diameter, Table 9).

In the following discussion sections, we will combine the information inferred from microstructures with mineral/whole-rock major element chemistry and $\mathrm{O}$ isotopic signature of olivine. Although the Rocca d'Argimonia sequence experienced extensive subsolidus re-equilibration, we will show that our methodological approach successfully brings information about the magmatic processes that gave rise to these deep-seated peridotites.

\subsection{Evidence for melt-peridotite reaction: the orthopyroxenite-websterite contact zone}

The Rocca d'Argimonia peridotites are locally crosscut by hornblende gabbronorite dykes typically showing a thickness variable from few centimetres to few tens of centimetres (Fig. 3b). These dykes display a millimetre-scale thick orthopyroxene-rich zone ( $54 \mathrm{vol} \%-94 \mathrm{vol} \%$, Table 10) along the contact with host peridotites, which consists of orthopyroxenite towards the peridotite and hornblende websterite towards the gabbronorite (Fig. 5c). In this section, 
we relate the development of this orthopyroxenite-websterite contact zone to a reaction driven by the chemical contrast between migrating melts and host peridotites.

The whole-rock chemical compositions of the gabbronorite dykes do not represent melt compositions. In particular, the thin dykes BI2/5 and BI10/3 have anomalously high Mg\# of 82-84 (Fig. 6), which most likely reflects a role of host dunites-harzburgites, in response to local dissolution and assimilation of peridotite material by the migrating melt and/or diffusive $\mathrm{Fe}-\mathrm{Mg}$ exchange between peridotite minerals and melt. The thick dykes BI8/1 and BI50/3 have $74-75 \mathrm{Mg} \#$ and relatively low $\mathrm{SiO}_{2} / \mathrm{Al}_{2} \mathrm{O}_{3}$ values of 2.4-2.7, which indicate a role of plagioclase accumulation (Kempton and Harmon, 1992). However, information about chemical compositions of the melts feeding the gabbronorite dykes may be acquired by mineral chemistry, based on experimentally determined mineral-melt coefficients. This approach assumes that original mineral compositions were not modified in response to the high temperature subsolidus reequilibration in the lower continental crust. Two-pyroxene geothermometry documented granulite facies metamorphic conditions, whereas the amphibole based methods yielded values of $\sim 1000^{\circ} \mathrm{C}$ (Table 11) that may be related to late magmatic conditions (cf. Nekvasil et al., 2004; Nandedkar et al., 2014). Hence, we used the chemical compositions of amphibole from thick gabbronorite dykes BI8/1 and BI50/3, for which the peridotite contribution was most likely negligible, to compute some compositional characteristics of the feeding melts.

The compilation of magmatic amphibole compositions by Putirka (2016) enables calculating the $\mathrm{SiO}_{2}$ content of the amphibole equilibrium melts, which corresponds to $50 \mathrm{wt} \%-$ $51 \mathrm{wt} \%$ for the BI8/1 and BI50/3 amphiboles. In addition, $\mathrm{Mg} \#$ and $\mathrm{TiO}_{2}$ of amphibole equilibrium melts may be computed assuming amphibole/basalt $\mathrm{Fe}-\mathrm{Mg}$ and Ti partition coefficients of 0.37 and 2.47 , respectively, as resulting from experiments carried out at $1010^{\circ} \mathrm{C}$ and $0.7 \mathrm{GPa}$ by Nandedkar et al. (2014, 2016). Calculations show that BI8/1 and BI50/3 amphiboles were in equilibrium with melts having 44-47 Mg\# and $1.1 \mathrm{wt} \%-1.2 \mathrm{wt} \% \mathrm{TiO}_{2}$. Amphibole compositions therefore document that the thick gabbronorite dykes crystallized from chemically evolved basaltic melts showing a marked chemical contrast with respect to host peridotites. For instance, the dunites and the harzburgites show $38 \mathrm{wt} \%-$ $40 \mathrm{wt} \% \mathrm{SiO}_{2}, 86-90 \mathrm{Mg} \#$ and $0.05 \mathrm{wt} \%-0.10 \mathrm{wt} \% \mathrm{TiO}_{2}$.

We computed the bulk chemical compositions of the micro-layers developing at the gabbronorite-peridotite contact (Table A2), based on their mineral and modal compositions. The mean calculated compositions of the two microlayers are compared with the mean compositions of host dunites-harzburgites in Fig. 14. The diagram shows that $\mathrm{MgO}$ and $\mathrm{FeO}_{\text {tot }}$ steadily decrease from the peridotite across the contact zone. Contrary to $\mathrm{MgO}$ and $\mathrm{FeO}_{\text {tot }}, \mathrm{Al}_{2} \mathrm{O}_{3}$ decreases from the websterite to the orthopyroxenite microlayer and the peridotite. $\mathrm{Cr}_{2} \mathrm{O}_{3}$ concentrations are similar in the peridotite and the adjacent orthopyroxenite microlayer and markedly decrease in the websterite micro-layer. The inferred $\mathrm{Al}_{2} \mathrm{O}_{3}$ and $\mathrm{Cr}_{2} \mathrm{O}_{3}$ variations from the peridotite across the contact zone are consistent with the Cr\# of orthopyroxene and spinel decreasing from the peridotite to the orthopyroxenite and the websterite micro-layers (Fig. 11). Mass balance calculations also show that the whole contact zone exhibits higher $\mathrm{SiO}_{2}$ than the dunites-harzburgites. In particular, because of the $18 \mathrm{vol} \%-22 \mathrm{vol} \%$ amphibole amount, the websterite micro-layer has slightly lower calculated $\mathrm{SiO}_{2}(44 \mathrm{wt} \%-46 \mathrm{wt} \%)$ than the orthopyroxenite micro-layer (49 wt \%-50 wt \%). Finally, $\mathrm{CaO}, \mathrm{Na}_{2} \mathrm{O}$ and $\mathrm{TiO}_{2}$ are low in the peridotite and the adjacent orthopyroxenite micro-layer, and they increase in the websterite microlayer, in response to the relatively high proportions of amphibole and clinopyroxene. For instance, calculated $\mathrm{TiO}_{2}$ is $0.1 \mathrm{wt} \%$ and $0.4 \mathrm{wt} \%$ for the orthopyroxenite and the websterite micro-layer, respectively.

We propose that the double-layered contact zone formed in response to a two-step reaction progress. The melt-peridotite reaction initiated with the development of the orthopyroxenite micro-layer (step 1). Most likely, the migrating melt had relatively high contents of $\mathrm{SiO}_{2}$ and $\mathrm{Al}_{2} \mathrm{O}_{3}$, which triggered the crystallization of orthopyroxene and minor spinel $(\sim 7 \mathrm{vol} \%)$. The similar $\mathrm{Cr}_{2} \mathrm{O}_{3}$ contents of the orthopyroxenite micro-layer and dunites-harzburgites (Fig. 14) suggest formation of the orthopyroxenite micro-layer by peridotite replacement, in response to peridotite dissolution by the migrating melt. Following the orthopyroxenite formation, excess $\mathrm{CaO}, \mathrm{Na}_{2} \mathrm{O}$ and $\mathrm{TiO}_{2}$ from the reacting melt could promote crystallization of amphibole and clinopyroxene, in association with orthopyroxene and spinel, thereby giving rise to the websterite micro-layer (step 2). Presumably, the relatively low $\mathrm{Cr}_{2} \mathrm{O}_{3}$ content of the websterite micro-layer (estimated as $\sim 0.2 \mathrm{wt} \%$ ) reflects the minor $\mathrm{Cr}_{2} \mathrm{O}_{3}$ content of the migrating melt with respect to host peridotite, the limited $\mathrm{Cr}$ diffusion from the peridotite to the melt and the earlier crystallization of spinel in the orthopyroxenite micro-layer. The original melt-peridotite boundary could therefore be the present contact between the orthopyroxenite and the websterite micro-layer. The melt-peridotite reaction also implies that the chemical elements that are incompatible with respect to the websterite mineral assemblage were concentrated in a residual melt, which could ultimately mix with the migrating melt that was not in physical contact with host peridotite. In particular, a significant proportion of original melt $\mathrm{TiO}_{2}$ was probably focused into the unreacted migrating melt.

To conclude, upward melt migration into the consolidated peridotites of the Rocca d'Argimonia sequence triggered a reaction that most likely involved dissolution of a millimetrescale thick peridotite layer, followed by orthopyroxenite and websterite crystallization and mixing of the residual melt with unreacted migrating melt. Such a dissolutioncrystallization process is similar to the series of reactions inferred for formation of Cabo Ortegal (Spain) mantle py- 
roxenites at the metre scale, by reaction between a boninitetype melt and a dunite (Tilhac et al., 2016). We propose that the melts interacting with the Rocca d'Argimonia peridotites were chemically evolved basalts, based on chemical compositions of amphibole from the thick gabbronorite dykes.

\subsection{Origin of the harzburgites and the lherzolites by reactive melt migration}

Whole-rock and mineral chemistry of the Rocca d'Argimonia peridotites show Mg\# decreasing from the dunites to the harzburgites and the lherzolites (Figs. 6, 7 and 8). Hence, the peridotite sequence could hypothetically be related to a fractional crystallization process involving early separation of olivine and accessory spinel, thereby giving rise to the dunites, followed by a stage forming the harzburgites and the lherzolites, ruled by segregation of olivine and accessory spinel together with orthopyroxene and minor clinopyroxene. This process could explain not only the olivine forsterite variations, but also the $\mathrm{Mg \# -Cr \#}$ correlation observed for orthopyroxene and clinopyroxene (Fig. 8), which may be reconciled with a plagioclase-free fractional crystallization process involving accessory spinel segregation. The rough positive correlation provided by the olivine-spinel pairs, with the forsterite proportion and the spinel Cr\# decreasing from $90 \mathrm{~mol} \%$ to $85 \mathrm{~mol} \%$ and from $29 \mathrm{~mol} \%$ to $11 \mathrm{~mol} \%$, respectively (Fig. 9), could also be consistent with a magmatic evolution controlled by fractionation of olivine and accessory spinel.

Fractional crystallization experiments from anhydrous and hydrous tholeiitic basalts at $0.7 \mathrm{GPa}$ (Villiger et al., 2007; Nandedkar et al., 2014) show that the early olivine-only fractionation stage, forming dunites, is followed by a phase in which olivine crystallizes together with clinopyroxene to give rise to wehrlites. These experimental results therefore argue against formation of the Rocca d'Argimonia peridotites through closed system fractional crystallization, because the chemically evolved Rocca d'Argimonia peridotites (i.e. the harzburgites and the lherzolites) exhibit minor clinopyroxene and a wide range of olivine / orthopyroxene modal ratio (Fig. 4a, Table 9). A process of closed system fractional crystallization controlled by olivine separation is also inconsistent with the forsterite- $\mathrm{NiO}$ variations of the Rocca d'Argimonia olivines (Fig. 7), which do not follow the expected olivine fractionation trend (e.g. Su et al., 2016). For instance, olivine from lherzolite BI30/5 displays the lowest forsterite proportion $(85 \mathrm{~mol} \%)$, suggesting formation from a relatively evolved melt, but is characterized by the highest $\mathrm{NiO}$ content $(0.36 \mathrm{wt} \%)$.

In the Rocca d'Argimonia harzburgites, orthopyroxene occurs as poikilitic grains enclosing olivine and spinel (Figs. 3a and 5a). Poikilitic orthopyroxene grains are locally also present in associated lherzolites. Olivine within orthopyroxene typically displays anhedral morphology with lobate boundaries, thereby indicating that olivine was partly dis- solved by an orthopyroxene-saturated melt. The poikilitic orthopyroxene therefore might grow from a melt relatively rich in $\mathrm{SiO}_{2}$ that reacted with olivine and partially digested it. Similar olivine-orthopyroxene replacement relationships were described for other ultramafic magmatic sequences intruding the upper continental crust (Barnes et al., 2016; Kaufmann et al., 2018; Mao et al., 2019). These studies agreed that poikilitic orthopyroxene did not form by closed-system peritectic reaction between olivine and residual melt. Barnes et al. (2016) and Kaufmann et al. (2018) argued for a reaction between olivine and an upward-migrating orthopyroxenesaturated melt, which formed by olivine fractionation in the crystal mush below. Mao et al. (2019) proposed that orthopyroxene saturation in the melt was due to $\mathrm{SiO}_{2}$ addition by wall-rock contamination, mainly based on oxygen isotopic compositions of olivine $\left(\delta^{18} \mathrm{O}=6.1 \%\right.$ - $7.2 \%$; see also Fig. 10).

The $\delta^{18} \mathrm{O}$ variability of the Rocca d'Argimonia olivines also argues for formation of the Rocca d'Argimonia peridotites by an open-system magmatic process. The $\delta^{18} \mathrm{O}_{\mathrm{O}}$ gradually increases from $+5.8 \%$ o to $+6.6 \%$ with lowering forsterite proportion from $90 \mathrm{~mol} \%$ to $85 \mathrm{~mol} \%$ (Fig. 10). Fractional crystallization is expected to produce a negligible or minor $\delta^{18} \mathrm{O}_{\mathrm{Ol}}$ increase $(<0.2 \%)$ for the limited forsterite range of the Rocca d'Argimonia olivines (e.g. Eiler, 2001; Bindeman et al., 2004; Bucholz et al., 2017; Yao et al., 2019). Hence, the negative $\delta^{18} \mathrm{O}$-forsterite correlation of the Rocca d'Argimonia olivines requires an external contaminating source with high $\delta^{18} \mathrm{O}$. We will discuss about the nature of this external source in the next discussion section.

The development of an orthopyroxene-dominated reaction zone between the gabbronorite dykes and host peridotites (Fig. 5c) is consistent with the idea (Barnes et al., 2016; Kaufmann et al., 2018; Mao et al., 2019) that poikilitic orthopyroxene in the harzburgites and the lherzolites formed by an open-system reactive melt flux. In the Rocca d'Argimonia peridotites, the occurrence of gabbronorite dykelets showing sinuous boundaries and of gabbronorite dykes with sharp planar boundaries suggests repeated melt injections during peridotite cooling. Hence, buoyant melts could also have pervasively migrated through a high-temperature olivine-rich matrix, thereby causing partial replacement of olivine by orthopyroxene.

Origin of the Rocca d'Argimonia harzburgites-lherzolites by reactive melt migration may explain the lack of correlation between forsterite and $\mathrm{NiO}$ contents of olivine (Fig. 7). The lower oceanic crustal rocks frequently show forsterite$\mathrm{NiO}$ olivine variations deviating from expected olivine fractional crystallization trends, and these divergences are typically interpreted to reflect post-cumulus magmatic reactions (Yang et al., 2019 and references therein). In particular, olivine with higher $\mathrm{NiO}$ at a given forsterite content than predicted by olivine fractionation models may be produced by the following (i) decreasing olivine mass, in response to melt-driven partial dissolution, and (ii) a reacting melt having 
relatively low Mg\#, which is associated with a high olivinemelt partition coefficient for Ni (Hart and Davis, 1978).

We envision the following reaction (mineral abbreviations after Whitney and Evans, 2010) for the partial replacement of olivine by poikilitic orthopyroxene in the Rocca d'Argimonia harzburgites-lherzolites :

$\mathrm{Ol}+\mathrm{SiO}_{2}$-rich melt $1=$

Opx + melt 2,

where melt 1 is the buoyantly rising evolved melt, and melt 2 is the fraction of the melt residual after the reaction with olivine. Because olivine is obviously preserved and spinel is also present within the olivine-orthopyroxene association, the reaction envisaged should be properly expressed as

$\mathrm{Ol} 1+\mathrm{Spl} 1+\mathrm{SiO}_{2}$-rich melt $1=$

$\mathrm{Opx}+\mathrm{Ol} 2+\mathrm{Spl} 2+$ melt 2 .

This formulation implies that olivine was originally associated with accessory spinel, and that both phases were not completely dissolved in response to the reaction with the infiltrating melt. The occurrence of olivine and spinel among reaction products denotes a conceivable compositional change of these phases ruled by the interaction with the melt. Notably, the relatively high proportion of spinel ( $6 \mathrm{vol} \%-9 \mathrm{vol} \%$ ) hosted by the poikilitic orthopyroxene suggests that spinel might also have precipitated in conjunction with the olivine-melt reaction.

Crystallization of new spinel by melt-peridotite reaction is shown by the orthopyroxenite-websterite reaction zone along the contact between peridotites and crosscutting gabbronorite dykes. Remarkably, the orthopyroxenespinel pairs from the orthopyroxenite micro-layer, adjacent to the peridotite in the reaction contact zone (Fig. 5c), follow the Cr\# spinel-orthopyroxene covariation depicted by the harzburgites-lherzolites (Fig. 11). Assuming that the original spinel (Spl 1 in Reaction R2) was chemically homogeneous, the spinel-orthopyroxene $\mathrm{Cr} \#$ variations observed for the harzburgites-lherzolites may be mostly related to different melt / crystal matrix ratios, with Cr\# diminishing with increasing melt proportion. The low $\mathrm{Cr} \#$ of orthopyroxene and spinel from the orthopyroxenite micro-layer was presumably due to a relatively high melt/peridotite ratio, which led to total consumption of olivine.

The gabbronorite-peridotite contact zone also includes a significant proportion of clinopyroxene and amphibole, in the websterite micro-layer adjacent to the gabbronorite. The crystallization of clinopyroxene ( $2 \mathrm{wt} \%-14 \mathrm{wt} \%)$ and amphibole ( $1 \mathrm{wt} \%-2 \mathrm{wt} \%)$ in the harzburgites and the lherzolites could therefore be promoted by the process of reactive melt migration. Evidence for late clinopyroxene crystallization is shown by lherzolite BI6/2, in which poikilitic clinopyroxene enclosing olivine and minor spinel occurs (Fig. 5b). The complete reaction for the melt flow process leading to formation of the Rocca d'Argimonia harzburgites-lherzolites may therefore be schematized as follows:

$\mathrm{Ol} 1+\mathrm{Spl} 1+\mathrm{SiO}_{2}$-rich melt $1=$

$\mathrm{Opx}+\mathrm{Ol} 2+\mathrm{Spl} 2+\mathrm{Cpx}+\mathrm{Amp}+$ melt 2 .

In summary, we attribute the development of poikilitic orthopyroxene in the Rocca d'Argimonia harzburgiteslherzolites to diffuse, reactive migration of melts relatively rich in $\mathrm{SiO}_{2}$ into a crystal matrix consisting of olivine and accessory spinel. Because one of the Rocca d'Argimonia peridotite layers (Fig. 2) entirely consists of harzburgites and minor lherzolites, the process of reactive melt flow must have operated at least at the scale of $\sim 100 \mathrm{~m}$. The peridotites subsequently underwent a similar melt-peridotite reaction, ruled by injection of chemically evolved basalts into solidified peridotites, which produced a millimetrescale orthopyroxenite-websterite layer along the contact with crosscutting gabbronorite dykes (see previous section).

\subsection{Origin of the dunites and the process of contaminating melt flow}

The Ivrea-Verbano Zone comprises several mantle sequences, mostly at its stratigraphic base (e.g. Balmuccia and Finero massifs), which include dunite bodies formed by focused reactive flow of olivine-saturated melts into lherzolites (Mazzucchelli et al., 2009) or harzburgites (Bussolesi et al., 2019; Corvò et al., 2020). These mantle replacive dunites are compositionally distinct with respect to the most primitive dunites of the Rocca d'Argimonia sequence (Figs. 6-9). For instance, the Balmuccia and the Finero replacive dunites have forsterite-richer olivine and Cr-richer spinel than the Rocca d'Argimonia dunites. A hypothetical mantle origin for the Rocca d'Argimonia dunites is also difficult to reconcile with the peridotite-pyroxenite alternations (Fig. 2) recalling a large-scale magmatic layering.

The microstructural characteristics and the compositional variations observed for the Rocca d'Argimonia dunites indicate that these rocks underwent reactive melt flow, according to Reaction (R3), as envisaged for associated harzburgites-lherzolites. Orthopyroxene from the dunites $(1 \mathrm{vol} \%-5 \mathrm{vol} \%)$ is typically interstitial with respect to olivine, or it forms relatively large grains with anhedral morphology, thereby indicating a late growth with respect to olivine. In the forsterite vs. $\delta^{18} \mathrm{O}_{\mathrm{Ol}}$ diagram (Fig. 10), the dunites, the harzburgites and the lherzolites follow the same trend, with the dunite olivines showing the highest forsterite and the lowest $\delta^{18} \mathrm{O}_{\mathrm{Ol}}$ values. The whole peridotite sequence of Rocca d'Argimonia may therefore be related to a process of reactive melt flow through a melt-poor olivine-rich crystal mush or a pre-existing dunite of likely magmatic origin. Following this idea, the studied dunites formed in response to a decrease of melt / crystalline matrix ratio with ongoing melt migration. 


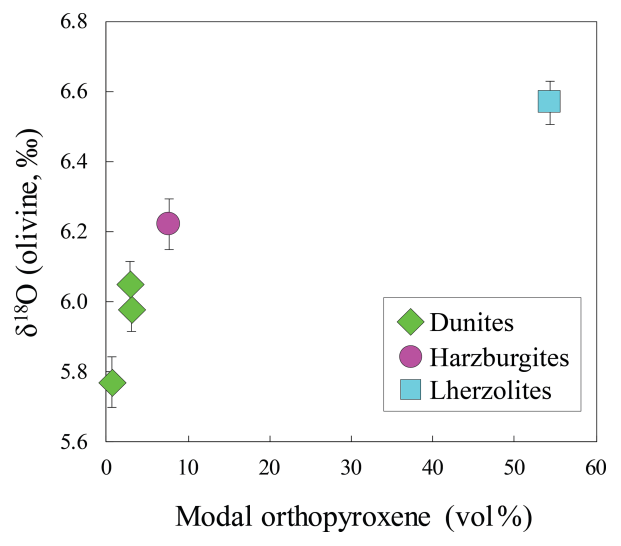

Figure 12. Plot of $\delta^{18} \mathrm{O}$ of olivine (weighted average $\pm 2 \sigma$ ) versus modal orthopyroxene for the Rocca d'Argimonia peridotites.

The $\delta^{18} \mathrm{O}_{\mathrm{Ol}}$ of the Rocca d'Argimonia peridotites increases not only with decreasing olivine forsterite proportion (Fig. 10) but also with increasing modal orthopyroxene (Fig. 12). In particular, the $\delta^{18} \mathrm{O}_{\mathrm{Ol}}$ increases from $+5.8 \%$ for dunite BI $4 / 1$ to $+6.6 \%$ o for lherzolite BI30/5, while modal orthopyroxene raises from 1 vol \% to $51 \mathrm{vol} \%$. The wide range of modal orthopyroxene in the studied peridotites is therefore attributed to a melt evolution comprising assimilation of crustal material, which promoted the crystallization of orthopyroxene. The $\delta^{18} \mathrm{O}_{\mathrm{Ol}}$ variability $(+6.1 \%$ to $+7.2 \%$, Fig. 10) observed for the lherzolites and the olivine websterites from Huangshanxi mafic-ultramafic intrusion (northwestern China) was similarly related to crustal contamination (Mao et al., 2019). In particular, the growth of poikilitic orthopyroxene in these rocks was attributed to downward convection of cool, Si-rich magma from the roof into an olivinerich crystal mush.

The Rocca d'Argimonia olivines could crystallize from crustally contaminated magmas. For instance, cooling of a mantle magma emplaced into the lower continental crust could lead to fractional crystallization and concomitant assimilation of basement material (i.e. the AFC process of DePaolo, 1981). Following this hypothesis, the oxygen isotopic signature of olivine was acquired before the reactive melt migration denoted by Reaction (R3). However, we speculate that an AFC-type process would result in direct orthopyroxene crystallization, rather than in the olivineorthopyroxene replacing relationships (Fig. 5a) typical of the Rocca d'Argimonia harzburgites-lherzolites. The hypothetical AFC-type process is also expected to produce a progressive decrease of forsterite and $\mathrm{NiO}$ contents in olivine, which is not observed for the Rocca d'Argimonia peridotites (Fig. 7). Hence, we favour an alternative petrogenetic scenario, which implies that the melt reactively migrating through the olivine-rich matrix possessed a substantial crustal component. Following this model, the reactive melt flow promoted the crystallization of orthopyroxene and modified the mantle-derived $\delta^{18} \mathrm{O}$ signature of pre-existing olivine. The envisaged petrogenetic process could be therefore coined as contaminating melt flow.

Two main hypotheses may be formulated for the source of the crustal component. The melt migrating through the olivine-rich matrix could have experienced assimilation of crustal material by mixing with a melt derived from preexisting material of the Ivrea Mafic Complex, either a solid gabbroic rock or a gabbroic crystal mush. This hypothesis is consistent with the Ivrea Mafic Complex made up of gabbroic rocks formed by mantle melts variably contaminated by crustal material (Voshage et al., 1990). Accordingly, the Ivrea Mafic Complex gabbroic rocks have relatively high $\delta^{18} \mathrm{O}$ (Fig. 13), which ranges from $+6.3 \%$ to $+10.1 \%$ (Sinigoi et al., 1991, 1994). In the second hypothesis, the reactively migrating melts mixed with crustal melts released by metasedimentary rocks present at depth, for instance in a septum of country rock embedded within the deepest Ivrea Mafic Complex. The metasediments of the Kinzigite Formation actually have high whole-rock $\delta^{18} \mathrm{O}$ ranging from $+10.0 \%$ to $+14.1 \%$ (Schnetger, 1994) and include quartz grains with $\delta^{18} \mathrm{O}$ ranging from $+9.1 \%$ to $+17.2 \%$ (Baker, 1990).

In spite of the wide range of oxygen isotopic compositions observed for both the rocks of the Kinzigite Formation and the Ivrea Mafic Complex, it is feasible that a lower amount of crustal component is required if the Kinzigite Formation was the contaminant rather than the Ivrea Mafic Complex. The extent of crustal component in the Rocca d'Argimonia peridotites may be roughly evaluated assuming that the $\delta^{18} \mathrm{O}_{\mathrm{Ol}}$ variations were only related to the process of crustal contamination. The $\Delta \delta^{18} \mathrm{O}_{\mathrm{Ol}}$ between the most primitive dunite BI4/1 and the most evolved lherzolite BI30/5 (0.8\%o) implies that the lherzolite had $12 \%$ higher crustal contribution than the dunite, if the contaminant material had the average $\delta^{18} \mathrm{O}$ of the Kinzigite Formation metasediments $(+12.5 \%$, Fig. 13). Assuming the average $\delta^{18} \mathrm{O}$ of the mafic rocks from the Ivrea Mafic Complex $(+8.1 \%$ ) as the contaminant material, the lherzolite had $34 \%$ higher mafic crust component than the dunite.

To conclude, we propose that the crustal contamination recorded by the Rocca d'Argimonia peridotites was accomplished by reactive flow of crustally contaminated melts through an olivine-rich spinel-bearing matrix. A possible conceptual model for the contaminating melt flow implies that an evolved melt of mantle origin mixed with a melt derived from either metasedimentary or gabbroic material and subsequently migrates upwards, thereby reacting with the olivine + spinel matrix and ultimately giving rise to the studied peridotites.

\subsection{Implications for mantle sources}

The most primitive dunites BI $4 / 1$ and BI $4 / 3$ of the Rocca d'Argimonia sequence have extremely low orthopyroxene amounts (1 vol\%, Table 9). Olivine from these rocks has 


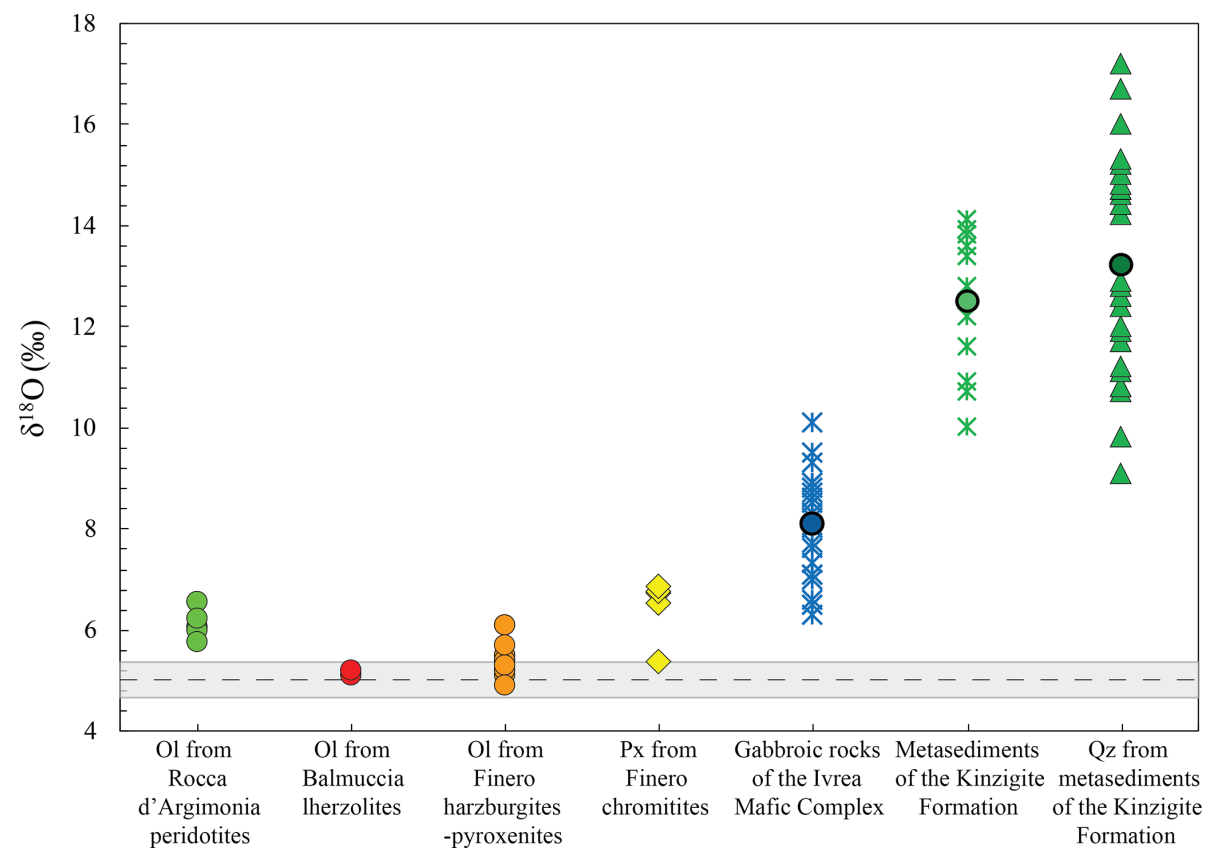

Figure 13. $\delta^{18} \mathrm{O}$ of olivine from the Rocca d'Argimonia peridotites compared with $\delta^{18} \mathrm{O}$ of other minerals/rocks from the Ivrea-Verbano Zone. Olivines from dunites, harzburgites and lherzolites of Rocca d'Argimonia are reported with the same symbol. Olivine from spinel lherzolites of the Balmuccia mantle sequence after Selverstone and Sharp (2011). Olivine from harzburgites and pyroxenites of the Finero mantle sequence after Selverstone and Sharp (2011). Orthopyroxene and clinopyroxene from chromitites of the Finero mantle sequence after Zanetti et al. (2016). Gabbroic rocks from the Ivrea Mafic Complex after Sinigoi et al. (1991, 1994); the dot represents the mean value of $+8.1 \%$. Metasediments of the Kinzigite Formation after Schnetger (1994); the dot represents the mean value of $+12.5 \%$. Quartz from metasediments of the Kinzigite Formation after Baker et al. (1990); the dot represents the mean value of $+13.2 \%$. The grey field represents the $\delta^{18} \mathrm{O}$ of typical mantle olivines (Mattey et al., 1994). Mineral abbreviations after Whitney and Evans (2010).

$89.9 \mathrm{~mol} \%$ forsterite and $0.34 \mathrm{wt} \%-0.35 \mathrm{wt} \% \mathrm{NiO}$ (Fig. 7), and it could therefore be in equilibrium with a primary mantle melt (e.g. Korenaga and Kelemen, 2000). Hence, the most primitive dunites could represent peridotite domains that escaped the process of contaminating melt flow envisaged in the previous section.

The $\delta^{18} \mathrm{O}_{\mathrm{Ol}}$ of dunite $\mathrm{BI} 4 / 1(+5.8 \pm 0.1 \%$ ) slightly exceeds (Fig. 10) the $\delta^{18} \mathrm{O}$ range defined by typical mantle olivines $(+5.2 \pm 0.3 \%$, Mattey et al., 1994). Hence, the melts giving rise to the olivine-rich matrix precursor of the Rocca d'Argimonia peridotites could primarily have anomalously high $\delta^{18} \mathrm{O}$, inherited from the mantle source. Locmelis et al. (2016) and Berno et al. (2020) reported similar ideas for other magmatic peridotites from the Ivrea-Verbano Zone, the ultramafic pipes and the Monte Capio-Alpe Cevia sequence, respectively. In particular, they proposed that the primitive melts forming these peridotites were generated from a subcontinental lithospheric mantle variably metasomatized during the Variscan subduction. Notably, olivine and pyroxene from the phlogopite-bearing mantle sequence of Finero (Selverstone and Sharp, 2011; Zanetti et al., 2016), in the northernmost sector of the Ivrea-Verbano Zone, locally show $\delta^{18} \mathrm{O}$ exceeding the typical $\delta^{18} \mathrm{O}$ mantle range (Fig. 13). These relatively high $\delta^{18} \mathrm{O}$ values were attributed to contamination of the Finero mantle sequence through melts sourced in a subducted continental crust, most likely in prePermian times (see also Hartmann and Wedepohl, 1993). Hence, the isotopic record in the Finero mantle sequence supports the potential occurrence of mantle sources producing $\delta^{18} \mathrm{O}$-enriched primitive melts during the late-post collisional Variscan evolution.

In an alternative petrogenetic scenario, the dunite BI4/1 was affected, to a minor extent, by the process of contaminating melt flow. Following this hypothesis, the low amount of orthopyroxene in this rock, even with respect to clinopyroxene and amphibole, could reflect the evolved nature of the melt reacting with the original olivine-rich matrix. Similar to what is inferred for step 2 of the melt-peridotite reaction forming the contact websterite micro-layer (Fig. 5c), the process of reactive melt flow through the olivine-rich matrix might increase the concentrations of $\mathrm{Ca}, \mathrm{Na}$ and $\mathrm{Ti}$ in the migrating melt. Hence, the highly evolved migrating melts could ultimately lead to a predominance of clinopyroxene and amphibole with respect to orthopyroxene in the mineral reaction products, as observed for the dunites BI $4 / 1$ and BI4/3. Assuming that the dunite olivine BI4/1 recorded the process of contaminating melt flow, the olivine-rich matrix 


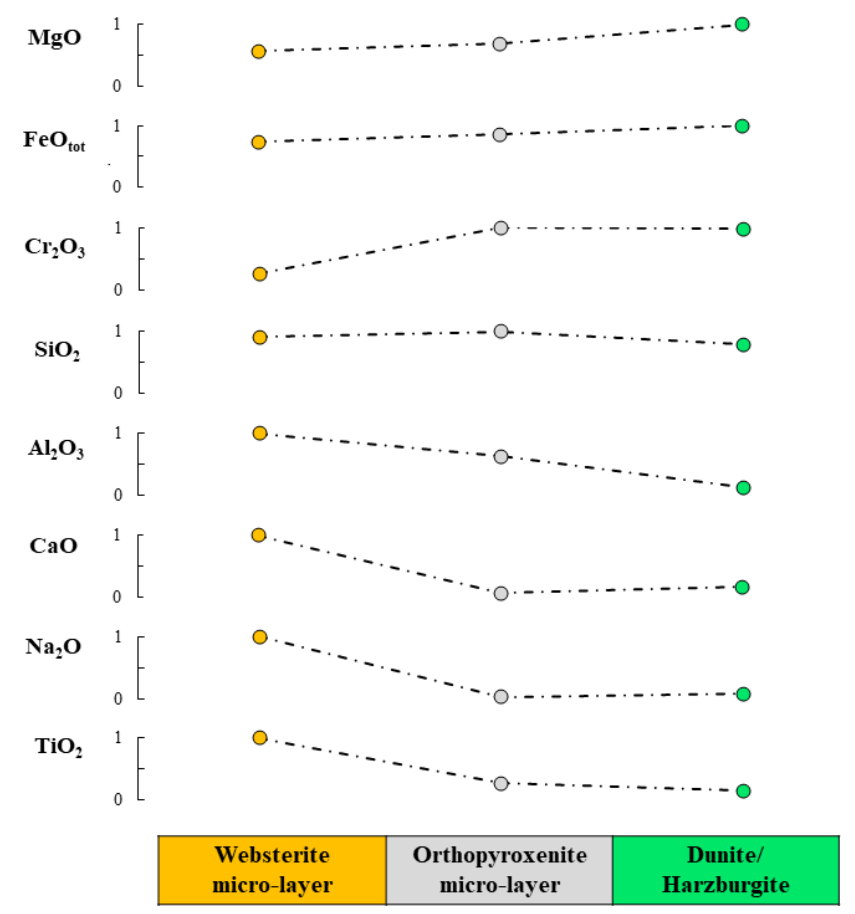

Figure 14. Mean compositions of the Rocca d'Argimonia dunitesharzburgites compared with the mean calculated bulk compositions of orthopyroxenite and websterite micro-layers (Table A2). To show the relative chemical variability from the peridotites across the contact zone, oxide concentrations are normalized to the highest content among peridotite, orthopyroxenite and websterite.

precursor of the Rocca d'Argimonia peridotites could for instance originally have $+5.5 \% \circ \delta^{18} \mathrm{O}$ and $91 \mathrm{~mol} \%$ forsterite.

We conclude that the process of contaminating melt migration could have erased the original chemical signature of the olivine-rich matrix precursor of the Rocca d'Argimonia peridotites. Further geochemical investigations are therefore needed to elucidate whether the mantle melts giving rise to the Rocca d'Argimonia ultramafic sequence were derived from mantle sources metasomatized by the Variscan subduction.

\section{Summary and concluding remarks}

The Ivrea Mafic Complex of the Ivrea Verbano Zone is $\sim 8 \mathrm{~km}$ thick gabbroic-dioritic intrusion in the lower continental crust (e.g. Quick et al., 1992; Sinigoi et al., 2011), developed in conjunction with the post-collisional transtensional regime of the Variscan orogeny (e.g. Handy et al., 1999; Wilson et al., 2004). The lower Ivrea Mafic Complex includes the peridotite-pyroxenite sequence of Rocca d'Argimonia, which is here considered of magmatic origin, in accordance with Sinigoi et al. (1991) and Quick et al. (2003).
The Rocca d'Argimonia peridotites compositionally range from dunites to harzburgites and minor clinopyroxene-poor lherzolites. Despite the extensive subsolidus re-equilibration under granulite facies conditions, the peridotites and the crosscutting gabbronorite dykes typically retain structures and microstructures of magmatic origin. In particular, the harzburgites and the lherzolites are characterized by the presence of poikilitic orthopyroxenes enclosing partially dissolved olivine and minor spinel. The gabbronorite dykes most likely formed by chemically evolved basalts and show millimetre-scale thick, orthopyroxenite to websterite reaction zones along the contact with host peridotites. The development of these reaction zones is attributed to a meltperidotite reaction comprising the following: (i) dissolution of a millimetre-scale thick peridotite layer, (ii) orthopyroxenite and websterite crystallization, and (iii) mixing of the melt residual after orthopyroxenite-websterite crystallization with unreacted migrating melt.

The compositional variations of the Rocca d'Argimonia peridotites cannot be related to a magmatic evolution process driven by closed system fractional crystallization. This notion is for instance shown the $\delta^{18} \mathrm{O}_{\mathrm{Ol}}$ significantly increasing with decreasing olivine forsterite proportion and with increasing modal orthopyroxene. Most likely, the peridotites record a process of reactive melt flow through a melt-poor olivine-rich crystal mush or a pre-existing dunite of likely magmatic origin. We propose that the reactively migrating melts possessed a substantial crustal component and were compositionally similar to those forming the gabbronorite dykes. The process of contaminating melt flow is considered to be responsible for the olivine dissolution shown by the poikilitic orthopyroxenes in the harzburgites-lherzolites and is inferred to have operated at least at the scale of $\sim 100 \mathrm{~m}$. The nature of the primitive melt forming the precursor olivine-rich matrix remains unknown.

Similar reactive melt flow relationships, with an early olivine-rich matrix percolated by basic melts, were proposed for other peridotite-pyroxenite sequences associated with the Ivrea Mafic Complex of the Ivrea Verbano Zone, namely the so-called ultramafic pipes (Locmelis et al., 2016) and the Monte Capio-Alpe Cevia sequence (Berno et al., 2020). The mineral reaction products in those cases differ in the relatively high proportion of amphibole and, locally, in the presence of phlogopite, most likely in response to involvement of primitive mantle melts with different compositions. Reactive melt flow through an olivine-dominated matrix in the lower crust, possibly associated with crustal contamination, may therefore represent a common process of large-scale magmatic systems growing in extensional continental settings. 


\section{Appendix A}

Table A1. Computed whole-rock chemical compositions of selected samples resulting from mass balance calculations, based on observed mineral compositions (Tables 2-7) and estimated mineral proportions (Table 9).

\begin{tabular}{|c|c|c|c|c|c|c|c|c|c|c|c|c|c|}
\hline Sample & $\mathrm{BI} 4 / 3$ & $\mathrm{BI} 4 / 1$ & $\mathrm{BI} 10 / 3$ & BI10/1 & $\mathrm{BI} 5 / 1$ & $\mathrm{BI} 2 / 1$ & $\mathrm{BI} 2 / 7$ & $\mathrm{BI} 6 / 2$ & $\mathrm{BI} 30 / 5$ & $\mathrm{BI} 2 / 5$ & BI10/3 & $\mathrm{BI} 8 / 1$ & $\mathrm{BI} 50 / 3$ \\
\hline Rock type & \multicolumn{4}{|c|}{ Dunites } & & \multicolumn{2}{|c|}{ Harzburgites } & \multicolumn{2}{|c|}{ Lherzolites } & \multicolumn{4}{|c|}{ Gabbronorite dykes } \\
\hline $\mathrm{SiO}_{2}$ & 39.6 & 40.0 & 40.3 & 39.9 & 38.9 & 40.0 & 41.4 & 44.3 & 45.8 & 48.2 & 48.9 & 49.6 & 48.1 \\
\hline $\mathrm{TiO}_{2}$ & 0.06 & 0.06 & 0.06 & 0.05 & 0.09 & 0.11 & 0.06 & 0.17 & 0.17 & 0.36 & 0.48 & 0.40 & 0.38 \\
\hline $\mathrm{Al}_{2} \mathrm{O}_{3}$ & 1.45 & 1.48 & 1.58 & 1.37 & 2.90 & 2.34 & 1.82 & 3.35 & 4.47 & 22.2 & 13.1 & 18.7 & 19.6 \\
\hline $\mathrm{Cr}_{2} \mathrm{O}_{3}$ & 0.70 & 0.68 & 0.49 & 0.55 & 1.31 & 0.89 & 0.87 & 0.49 & 0.67 & 0.00 & 0.11 & 0.02 & 0.03 \\
\hline $\mathrm{FeO}$ (tot) & 9.80 & 9.79 & 11.2 & 11.7 & 11.5 & 12.1 & 11.9 & 11.4 & 12.0 & 3.22 & 5.98 & 6.26 & 6.90 \\
\hline $\mathrm{MnO}$ & 0.15 & 0.14 & 0.18 & 0.15 & 0.16 & 0.17 & 0.18 & 0.19 & 0.19 & 0.08 & 0.13 & 0.14 & 0.14 \\
\hline $\mathrm{NiO}$ & 0.32 & 0.33 & 0.27 & 0.25 & 0.32 & 0.26 & 0.22 & 0.14 & 0.18 & 0.00 & 0.03 & 0.02 & 0.03 \\
\hline $\mathrm{MgO}$ & 46.9 & 46.5 & 45.1 & 45.1 & 43.4 & 42.9 & 42.9 & 36.3 & 34.7 & 10.4 & 14.8 & 9.91 & 10.0 \\
\hline $\mathrm{CaO}$ & 0.95 & 0.94 & 0.78 & 0.83 & 1.38 & 1.17 & 0.68 & 3.48 & 1.69 & 13.9 & 15.6 & 13.1 & 13.2 \\
\hline $\mathrm{Na}_{2} \mathrm{O}$ & 0.06 & 0.06 & 0.05 & 0.05 & 0.09 & 0.08 & 0.05 & 0.14 & 0.12 & 1.65 & 0.82 & 1.75 & 1.61 \\
\hline $\mathrm{K}_{2} \mathrm{O}$ & & & & & & & & & & 0.04 & 0.02 & 0.05 & 0.04 \\
\hline Total & 100 & 100 & 100 & 100 & 100 & 100 & 100 & 100 & 100 & 100 & 100 & 100 & 100 \\
\hline
\end{tabular}

Table A2. Computed whole-rock compositions of orthopyroxenite and websterite micro-layers occurring along the contact between peridotites and crosscutting gabbronorite dykes BI2/5 and BI10/3. Calculations were carried out based on mineral (Tables 3-6) and modal compositions (Table 10). Volume mineral proportions were converted to weight mineral proportions based on the following densities: orthopyroxene $=3.3 \mathrm{~g} \mathrm{~cm}^{-3}$, clinopyroxene $=3.3 \mathrm{~g} \mathrm{~cm}^{-3}$, amphibole $=3.2 \mathrm{~g} \mathrm{~cm}^{-3}$ and spinel $=4.4 \mathrm{~g} \mathrm{~cm}^{-3}$. Obtained weight mineral proportions are as follows: (i) 91.8 orthopyroxene and 8.2 spinel for orthopyroxenite BI2/5, (ii) 88.9 orthopyroxene and 11.1 spinel for orthopyroxenite BI10/3, (iii) 56.8 orthopyroxene, 11.8 clinopyroxene, 20.9 amphibole and 10.6 spinel for websterite BI2/5, and (iv) 52.4 orthopyroxene, 15.6 clinopyroxene, 16.8 amphibole and 15.2 spinel for websterite BI10/3.

\begin{tabular}{lrr|rr}
\hline Sample & \multicolumn{2}{c|}{$\mathrm{BI} / 5$} & \multicolumn{2}{c}{$\mathrm{BI} 10 / 3$} \\
\hline Rock type & Orthopyroxenite & Websterite & Orthopyroxenite & Websterite \\
\hline $\mathrm{SiO}_{2}$ & 50.0 & 46.0 & 48.7 & 43.8 \\
$\mathrm{TiO}_{2}$ & 0.1 & 0.4 & 0.1 & 0.4 \\
$\mathrm{Al}_{2} \mathrm{O}_{3}$ & 8.4 & 13.3 & 9.9 & 15.8 \\
$\mathrm{Cr}_{2} \mathrm{O}_{3}$ & 0.6 & 0.2 & 1.0 & 0.3 \\
$\mathrm{FeO}$ (tot & 9.5 & 8.0 & 9.0 & 8.0 \\
$\mathrm{MnO}$ & 0.2 & 0.1 & 0.2 & 0.1 \\
$\mathrm{NiO}$ & 0.1 & 0.1 & 0.1 & 0.1 \\
$\mathrm{MgO}$ & 30.7 & 25.6 & 30.6 & 24.9 \\
$\mathrm{CaO}$ & 0.4 & 5.6 & 0.4 & 6.0 \\
$\mathrm{Na} 2 \mathrm{O}$ & 0.0 & 0.7 & 0.0 & 0.5 \\
$\mathrm{~K}_{2} \mathrm{O}$ & 0.0 & 0.1 & 0.0 & 0.0 \\
\hline $\mathrm{Total}$ & 100 & 100 & 100 & 100 \\
$\mathrm{Mg} \#$ & 85.2 & 85.0 & 85.8 & 84.8 \\
\hline
\end{tabular}


Data availability. All data derived from this research are presented in the enclosed figures and tables.

Supplement. The supplement related to this article is available online at: https://doi.org/10.5194/ejm-32-587-2020-supplement.

Author contributions. MA and RT performed the fieldwork. MA carried out the petrographic and mineral chemical analyses and the sample preparation for the whole-rock analyses. TL and FYW supervised the oxygen isotopic analyses of olivines, achieved by MA in Beijing. All authors discussed and interpreted the results. MA and RT prepared and reviewed the manuscript.

Competing interests. The authors declare that they have no conflict of interest.

Acknowledgements. We wish to express our gratitude to Jakub Ciazela and Romain Tilhac for their constructive and comprehensive reviews. We also thank Marco Scambelluri and Alberto Vitale Brovarone for stimulating suggestions and Ruben Pilotto for his help during fieldwork. Riccardo Tribuzio acknowledges Silvano Sinigoi for pleasant and inspiring discussions about formation of the Ivrea Mafic Complex.

Financial support. This research has been supported by the Programma di Rilevante Interesse Nazionale (Italy) (grant no. 2015C5LN35). This research was also financially supported by the Università degli Studi di Pavia.

Review statement. This paper was edited by Didier Laporte and reviewed by Jakub Ciazela and Romain Tilhac.

\section{References}

Baker, A. J.: Stable isotopic evidence for fluid-rock interactions in the Ivrea Zone, Italy, J. Petrol., 31, 243-260, 1990.

Barnes, S. J., Mole, D. R., Le Vaillant, M., Campbell, M. J., Verrall, M. R., Roberts, M. P., and Evans, N. J.: Poikilitic textures, heteradcumulates and zoned orthopyroxenes in the Ntaka Ultramafic Complex, Tanzania: implications for crystallization mechanisms of oikocrysts, J. Petrol., 57, 1171-1198, 2016.

Berno, D., Tribuzio, R., Zanetti, A., and Hémond, C.: Evolution of mantle melts intruding the lowermost continental crust: constraints from the Monte Capio-Alpe Cevia mafic-ultramafic sequences (Ivrea-Verbano Zone, northern Italy), Contrib. Mineral. Petr., 175, 2, https://doi.org/10.1007/s00410-019-1637-8, 2020.

Bertolani, M. and Loschi-Ghittoni, A. G.: La zona a ultrabasiti della Rocca D'Argimonia nelle Prealpi Biellesi. La petrografia, Rend. Soc. Ital. Mineral. Petr., 35, 791-813, 1979.

Bindeman, I. N., Ponomareva, V. V., Bailey, J. C., and Valley, J. W.: Volcanic arc of Kamchatka: a province with high- $\delta{ }^{18} \mathrm{O}$ magma sources and large-scale ${ }^{18} \mathrm{O} /{ }^{16} \mathrm{O}$ depletion of the upper crust, Geochim. Cosmochim. Act., 68, 841-865, 2004.

Boriani, A. and Giobbi, E.: Does the basement of western southern Alps display a tilted section through the continental crust? A review and discussion, Period. Mineral., 73, 5-22, 2004.

Brey, G. P. and Köhler, T.: Geothermobarometry in four-phase lherzolites II. New thermobarometers, and practical assessment of existing thermobarometers, J. Petrol., 31, 1353-1378, 1990.

Bucholz, C. E., Jagoutz, O., VanTongeren, J. A., Setera, J., and Wang, Z.: Oxygen isotope trajectories of crystallizing melts: Insights from modeling and the plutonic record, Geochim. Cosmochim. Act., 207, 154-184, 2017.

Bussolesi, M., Grieco, G., and Tzamos, E.: Olivine-Spinel Diffusivity Patterns in Chromitites and Dunites from the Finero Phlogopite-Peridotite (Ivrea-Verbano Zone, Southern Alps): Implications for the Thermal History of the Massif, Minerals, 9, 75, https://doi.org/10.3390/min9020075, 2019.

Chiba, H., Chacko, T., Clayton, R. N., and Goldsmith, J. R.: Oxygen isotope fractionations involving diopside, forsterite, magnetite, and calcite: Application to geothermometry, Geochim. Cosmochim. Act., 53, 2985-2995, 1989.

Corvò, S., Langone, A., Padrón-Navarta, J. A., Tommasi, A., and Zanetti, A.: Porphyroclasts: source and sink of major and trace elements during deformation-induced metasomatism (Finero, Ivrea Verbano Zone, Italy), Geosciences, 10, 196, https://doi.org/10.3390/geosciences10050196, 2020.

Demarchi, G., Quick, J. E., Sinigoi, S., and Mayer, A.: Pressure gradient and original orientation of a lower-crustal intrusion in the Ivrea-Verbano Zone, Northern Italy, J. Geol., 106, 609-622, 1998.

Denyszyn, S. W., Fiorentini, M. L., Maas, R., and Dering, G.: A bigger tent for CAMP, Geology, 46, 823-826, 2018.

DePaolo, D. J.: A neodymium and strontium isotopic study of the Mesozoic calc-alkaline granitic batholiths of the Sierra Nevada and Peninsula Ranges, California, J. Geophys. Res., 86, 1047010488, 1981.

Dohmen, R., Chakraborty, S., and Becker, H. W.: Si and O diffusion in olivine and implications for characterizing plastic flow in the mantle, Geophys. Res. Lett., 29, 2030, https://doi.org/10.1029/2002GL015480, 2002.

Eiler, J. M.: Oxygen isotope variations of basaltic lavas and upper mantle rocks, Rev. Mineral. Geochem., 43, 319-364, 2001.

Eiler, J. M., Baumgartner, L. P., and Valley, J. W.: Intercrystalline stable isotope diffusion: a fast grain boundary model, Contrib. Mineral. Petr., 112, 543-557, 1992.

Eiler, J. M., Valley, J. W., and Baumgartner, L. P.: A new look at stable isotope thermometry, Geochim. Cosmochim. Act., 57, 25712571, 1993.

Eiler, J. M., Farley, K. A., Valley, J. W., Stolper, E. M., Hauri, E. H., and Craig, H.: Oxygen isotope evidence against bulk recycled sediment in the mantle sources of Pitcairn Island lavas, Nature, 377, 138-141, 1995.

Ewing, T. A., Hermann, J., and Rubatto, D.: The robustness of the Zr-in-rutile and Ti-in zircon thermometers during high-temperature metamorphism (Ivrea-Verbano Zone, northern Italy), Contrib. Mineral. Petr., 4, 757-779, 2013.

Ferrario, A., Garuti, G., Rossi, A., and Sighinolfi, G. P. (Eds.): Petrographic and metallogenic outlines of the "La Balma-M. Capio" ultramafic-mafic body (Ivrea-Verbano basic complex, NW Italian 
Alps), in: Mineral Deposits of the Alps and of the Alpine Epoch in Europe, Springer, Berlin, Heidelberg, Germany, 28-40, 1983.

Fiorentini, M. L., LaFlamme, C., Denyszyn, S., Mole, D., Maas, R., Locmelis, M., Caruso, S., and Bui, T. H.: Post-collisional alkaline magmatism as gateway for metal and sulfur enrichment of the continental lower crust, Geochim. Cosmochim. Act., 223, 175-197, 2018.

Garuti, G., Bea, F., Zaccarini, F., and Montero, P.: Age, geochemistry and petrogenesis of the ultramafic pipes in the Ivrea Zone, NW Italy, J. Petrol., 42, 433-457, 2001.

Giletti, B. J.: Diffusion effects on oxygen isotope temperatures of slowly cooled igneous and metamorphic rocks, Earth Planet. Sc. Lett., 77, 218-228, 1986.

Guerguoz, C., Martin, L., Vanderhaeghe, O., Thébaud, N., and Fiorentini, M.: Zircon and monazite petrochronologic record of prolonged amphibolite to granulite facies metamorphism in the Ivrea-Verbano and Strona-Ceneri Zones, NW Italy, Lithos, 308309, 1-18, 2018.

Günther, T., Haase, K. M., Junge, M., Oberthür, T., Woelki, D., and Krumm, S.: Oxygen isotope and trace element compositions of platiniferous dunite pipes of the Bushveld Complex, South Africa-Signals from a recycled mantle component?, Lithos, 310 , 332-341, 2018.

Handy, M. R., Franz, L., Heller, F., Janott, B., and Zurbriggen, R.: Multistage accretion and exhumation of the continental crust (Ivrea crustal section, Italy and Switzerland), Tectonics, 18, 1154-1177, 1999.

Hart, S. R. and Davis, K. E.; Nickel partitioning between olivine and silicate melt, Earth Planet. Sc. Lett., 40, 203-219, 1978.

Hartmann, G. and Wedepohl, K. H.: The composition of peridotite tectonites from the Ivrea Complex, northern Italy: residues from melt extraction, Geochim. Cosmochim. Act., 57, 1761-1782, 1993.

Holland, T. and Blundy, J.: Non-ideal interactions in calcic amphiboles and their bearing on amphibole-plagioclase thermometry, Contrib. Mineral. Petr., 116, 433-447, 1994.

Jackson, M. D., Blundy, J., and Sparks, R. S. J.: Chemical differentiation, cold storage and remobilization of magma in the Earth's crust, Nature, 564, 405-409, 2018.

Karakas, O., Wotzlaw, J.-F., Guillong, M., Ulmer, P., Brack, P, Economos, R., Bergantz, G. W., Sinigoi, S., and Bachmann, O.: The pace of crustal-scale magma accretion and differentiation beneath silicic caldera volcanoes, Geology, 47, 719-723, 2019.

Kaufmann, F. E., Vukmanovic, Z., Holness, M. B., and Hecht, L.: Orthopyroxene oikocrysts in the MG1 chromitite layer of the Bushveld Complex: implications for cumulate formation and recrystallisation, Contrib. Mineral. Petr., 173, 17, https://doi.org/10.1007/s00410-018-1441-x, 2018.

Kempton, P. D. and Harmon, R. S.: Oxygen isotope evidence for large-scale hybridization of the lower crust during magmatic underplating, Geochim. Cosmochim. Act., 56, 971-986, 1992.

Klötzli, U. S., Sinigoi, S., Quick, J. E., Demarchi, G., Tassinari, C. C., Sato, K., and Günes, Z.: Duration of igneous activity in the Sesia Magmatic System and implications for high-temperature metamorphism in the Ivrea-Verbano deep crust, Lithos, 206, 1933, 2014.

Korenaga, J. and Kelemen, P. B.: Major element heterogeneity in the mantle source of the North Atlantic igneous province, Earth Planet. Sc. Lett., 184, 251-268, 2000.
Kruger, W. and Latypov, R.: Fossilized solidifications fronts in the Bushveld Complex argues for liquid-dominated magmatic systems, Nat. Commun., 11, 1-11, 2020.

Kunz, B. E. and White, R. W.: Phase equilibrium modelling of the amphibolite to granulite facies transition in metabasic rocks (Ivrea Zone, NW Italy), J. Metamorph. Geol., 37, 935-950, 2019.

Langone, A., Padrón-Navarta, J. A., Ji, W.-Q., Zanetti, A., Mazzucchelli, M., Tiepolo, M., Giovanardi, T., and Bonazzi, M.: Ductilebrittle deformation effects on crystal-chemistry and $\mathrm{U}-\mathrm{Pb}$ ages of magmatic and metasomatic zircons from a dyke of the Finero Mafic Complex (Ivrea-Verbano Zone, Italian Alps), Lithos, 284 285, 493-511, 2017.

Leake, B. E., Woolley, A. R., Arps, C. E., Birch, W. D., Gilbert, M. C., Grice, J. D., Hawthorne, F. C., Kato, A., Kisch, H. J., Krivovichev, V. G., Linthout, K., Laird, J., Mandarino, J., Maresch, W. V., Nickel, E. H., Tock, N. M. S., Schumacher, J. C., Smith, D. C., Stephenson, N. C. N., Ungaretti, L., Whittaker, E. J. W., and Youzhi, G.: Nomenclature of amphiboles; report of the Subcommittee on Amphiboles of the International Mineralogical Association Commission on new minerals and mineral names, Mineral. Mag., 61, 295-310, 1997.

Lensch, G.: Die Ultramafitite der Zone von Ivrea und ihre geologische Interpretation, Schweiz. Mineral. Petrogr. Mitt., 48, 91-102, 1968.

Lissenberg, C. J. and MacLeod, C. J.: A reactive porous flow control on the Mid-ocean ridge magmatic evolution, J. Petrol., 57, 21952220, 2016.

Locmelis, M., Fiorentini, M. L., Rushmer, T., Arevalo Jr, R., Adam, J., and Denyszyn, S. W.: Sulfur and metal fertilization of the lower continental crust, Lithos, 244, 74-93, 2016.

Mao, Y. J., Barnes, S. J., Qin, K. Z., Tang, D., Martin, L., Su, B., and Evans, N. J.: Rapid orthopyroxene growth induced by silica assimilation: constraints from sector-zoned orthopyroxene, olivine oxygen isotopes and trace element variations in the Huangshanxi $\mathrm{Ni}-\mathrm{Cu}$ deposit, Northwest China, Contrib. Mineral. Petr., 174, 33, https://doi.org/10.1007/s00410-019-1574-6, 2019.

Mattey, D., Lowry, D., and Macpherson, C.: Oxygen isotope composition of mantle peridotite, Earth Planet. Sc. Lett., 128, 231241, 1994.

Mazzucchelli, M., Rivalenti, G., Brunelli, D., Zanetti, A., and Boari, E.: Formation of highly refractory dunite by focused percolation of pyroxenite-derived melt in the Balmuccia peridotite massif (Italy), J. Petrol., 50, 1205-1233, 2009.

Mukasa, S. B. and Shervais, J. W.: Growth of subcontinental lithosphere: evidence from repeated dike injections in the Balmuccia lherzolite massif, Italian Alps, Lithos, 48, 287-316, 1999.

Nandedkar, R. H., Ulmer, P., and Müntener, O.: Fractional crystallization of primitive, hydrous arc magmas: an experimental study at $0.7 \mathrm{GPa}$, Contrib. Mineral. Petr., 167, 1015, https://doi.org/10.1007/s00410-014-1015-5, 2014.

Nandedkar, R. H., Hürlimann, N., Ulmer, P., and Müntener, O.: Amphibole-melt trace element partitioning of fractionating calcalkaline magmas in the lower crust: an experimental study, Contrib. Mineral. Petr., 171, 71, https://doi.org/10.1007/s00410-0161278-0, 2016.

Nekvasil, H., Dondolini, A., Horn, J., Filiberto, J., Long, H., and Lindsley, D. H.: The origin and evolution of silica-saturated alkalic suites: an experimental study, J. Petrol., 45, 693-721, 2004. 
Pistone, M., Müntener, O., Ziberna, L., Hetényi, G., and Zanetti, A.: Report on the ICDP workshop DIVE (Drilling the IvreaVerbano zonE), Sci. Dril., 23, 47-56, https://doi.org/10.5194/sd23-47-2017, 2017.

Putirka, K.: Amphibole thermometers and barometers for igneous systems and some implications for eruption mechanisms of felsic magmas at arc volcanoes, Am. Mineral., 101, 841-858, 2016.

Quick, J. E., Sinigoi, S., Negrini, L., Demarchi, G., and Mayer, A.: Synmagmatic deformation in the underplated igneous complex of the Ivrea-Verbano zone, Geology, 20, 613-616, 1992.

Quick, J. E., Sinigoi, S., and Mayer, A.: Emplacement of mantle peridotite in the lower continental crust, Ivrea-Verbano zone, northwest Italy, Geology, 23, 739-742, 1995.

Quick, J. E., Sinigoi, S., Snoke, A. W., Kalakay, T. J., Mayer, A., and Peressini, G.: Geologic map of the southern Ivrea-Verbano Zone northwestern Italy, U.S. Geological Survey, Geologic Investigations Series Map I-2776, scale 1:25000, 2003.

Redler, C., White, R. W., and Johnson, T. E.: Migmatites in the Ivrea Zone (NW Italy): constraints on partial melting and melt loss in metasedimentary rocks from Val Strona di Omegna, Lithos, 175, 40-53, 2013.

Rivalenti, G., Garuti, G., and Rossi, A.: The origin of the IvreaVerbano Basic Formation (Western Italian Alps) - whole rock geochemistry, Bol. Soc. Geol. It. 94, 1149-1186, 1975.

Rivalenti, G., Mazzucchelli, M., Vannucci, R., Hofmann, A. W., Ottolini, L., and Obermiller, W.: The relationship between websterite and peridotite in the Balmuccia peridotite massif (NW Italy) as revealed by trace element variations in clinopyroxene, Contrib. Mineral. Petr., 121, 275-288, 1995.

Rosenbaum, J. M., Kyser, T. K., and Walker, D.: High temperature oxygen isotope fractionation in the enstatite-olivine- $\mathrm{BaCO}_{3}$ system. Geochim. Cosmochim. Act., 58, 2653-2660, 1994.

Schmid, S. M., Kissling, E., Diehl, T., van Hinsbergen, D. J., and Molli, G.: Ivrea mantle wedge, arc of the Western Alps, and kinematic evolution of the Alps-Apennines orogenic system, Swiss J. Geosci., 110, 581-612, 2017.

Schnetger, B.: Partial melting during the evolution of the amphibolite-to granulite-facies gneisses of the Ivrea Zone, northern Italy, Chem. Geol., 113, 71-101, 1994.

Shervais, J. W. and Mukasa, S. B.: The Balmuccia orogenic lherzolite massif, Italy, J. Petrol., Special Lherzolite Issue, 155-174, 1991.

Selverstone, J. and Sharp, Z. D.: Chlorine isotope evidence for multicomponent mantle metasomatism in the Ivrea Zone, Earth Planet. Sc. Lett., 310, 429-440, 2011.

Sinigoi, S., Antonini, P., Demarchi, G., Longinelli, A., Mazzucchelli, M., Negrini, L., and Rivalenti, G.: Intractions of mantle and crustal magmas in the southern part of the Ivrea Zone (Italy), Contrib. Mineral. Petr., 108, 385-395, 1991.

Sinigoi, S., Quick, J. E., Clemens-Knott, D., Mayer, A., Demarchi, G., Mazzucchelli, M., Negrini, L., and Rivalenti, G.: Chemical evolution of a large mafic intrusion in the lower crust, IvreaVerbano Zone, northern Italy, J. Geophys. Res.-Sol. Ea., 99, 21575-21590, 1994.

Sinigoi, S., Quick, J. E., Mayer, A., and Demarchi, G.: Densitycontrolled assimilation of underplated crust, Ivrea-Verbano Zone, Italy, Earth Planet. Sc. Lett., 129, 183-191, 1995.

Sinigoi, S., Quick, J. E., Mayer, A., and Budahn, J. R.: Influence of stretching and density contrasts on the chemical evolution of continental magmas: an example from the Ivrea-Verbano Zone, Contrib. Mineral. Petr., 123, 238-250, 1996.

Sinigoi, S., Quick, J. E., Demarchi, G., and Klötzli, U. S: The role of crustal fertility in the generation of large silicic magmatic systems triggered by intrusion of mantle magma in the deep crust, Contrib. Mineral. Petr., 162, 691-707, 2011.

Sinigoi, S., Quick, J. E., Demarchi, G., and Klötzli, U. S.: Production of hybrid granitic magma at the advancing front of basaltic underplating: Inferences from the Sesia Magmatic System (south-western Alps, Italy), Lithos, 252, 109-122, 2016.

Solano, J. M. S., Jackson, M. D., Sparks, R. S. J., Blundy, J. D., and Annen, C.: Melt segregation in deep crustal hot zones: a mechanism for chemical differentiation, crustal assimilation and the formation of evolved magmas, J. Petrol., 53, 1999-2026, 2012.

Solano, J. M. S., Jackson, M. D., Sparks, R. S. J., and Blundy, J.: Evolution of major and trace element composition during melt migration through crystalline mush: implications for chemical differentiation in the crust, Am. J. Sci., 314, 895-939, 2014.

$\mathrm{Su}, \mathrm{B}$., Chen, Y., Guo, S., and Liu, J.: Origins of orogenic dunites: petrology, geochemistry, and implications, Gondwana Res., 29, 41-59, 2016.

Tilhac, R., Ceuleneer, G., Griffin, W. L., O'Reilly, S. Y., Pearson, N. J., Benoit, M., Henry, H., Girardeau, J., and Grégoire, M.: Primitive arc magmatism and delamination: petrology and geochemistry of Pyroxenites from the Cabo Ortegal Complex, Spain, J. Petrol., 57, 1921-1954, 2016.

Valley, J. W.: Stable isotope thermometry at high temperatures, Rev. Mineral. Geochem., 43, 365-413, 2001.

Vavra, G., Schmid, R., and Gebauer, D.: Internal morphology, habit and $\mathrm{U}-\mathrm{Th}-\mathrm{Pb}$ microanalysis of amphibolite-to-granulite facies zircons: geochronology of the Ivrea Zone (Southern Alps), Contrib. Mineral. Petr., 134, 380-404, 1999.

Villiger, S., Ulmer, P., Müntener, O., and Thompson, A. B.: The liquid line of descent of anhydrous, mantle-derived, tholeiitic liquids by fractional and equilibrium crystallization - an experimental study at 1.0 GPa, J. Petrol., 45, 2369-2388, 2004.

Villiger, S., Müntener, O., and Ulmer, P.: Crystallization pressures of mid-ocean ridge basalts derived from major element variations of glasses from equilibrium and fractional crystallization experiments, J. Geophys. Res.-Sol. Ea., 112, B01202, https://doi.org/10.1029/2006JB004342, 2007.

Voshage, H., Sinigoi, S., Mazzucchelli, M., Demarchi, G., Rivalenti, G., and Hofmann, A. W.: Isotopic constraints on the origin of ultramafic and mafic dikes in the Balmuccia peridotite (Ivrea Zone), Contrib. Mineral. Petr., 100, 261-267, 1988.

Voshage, H., Hofmann, A. W., Mazzucchelli, M., Rivalenti, G., Sinigoi, S., Raczek, I., and Demarchi, G.: Isotopic evidence from the Ivrea Zone for a hybrid lower crust formed by magmatic underplating, Nature, 347, 731-736, 1990.

Wells, P. R.: Pyroxene thermometry in simple and complex systems, Contrib. Mineral. Petr., 62, 129-139, 1977.

Whitney, D. L. and Evans, B. W.: Abbreviations for names of rockforming minerals, Am. Mineral., 95, 185-187, 2010.

Wilson, M., Neumann, E. R., Davies, G. R., Timmerman, M. J., Heeremans, M., and Larsen, B. T.: Permo-Carboniferous magmatism and rifting in Europe: introduction, Geol. Soc. Sp, 223 , 1-10, 2004. 
Yang, A. Y., Wang, C., Liang, Y., and Lissenberg, C. J.: Reaction between mid-ocean ridge basalt and lower oceanic crust: An experimental study, Geochem. Geophy. Geosy., 20, 4390-4407, 2019.

Yao, J. H., Zhu, W. G., Li, C., Zhong, H., Yu, S., Ripley, E. M., and Bai, Z. J.: Olivine $\mathrm{O}$ isotope and trace element constraints on source variation of picrites in the Emeishan flood basalt province, SW China, Lithos, 338, 87-98, 2019.

Zaccarini, F., Garuti, G., Fiorentini, M. L., Locmelis, M., Kollegger, P., and Thalhammer, O. A.: Mineralogical hosts of platinum group elements (PGE) and rhenium in the magmatic $\mathrm{Ni}-\mathrm{Fe}-\mathrm{Cu}$ sulfide deposits of the Ivrea Verbano Zone (Italy): an electron microprobe study, J. Mineral. Geochem., 191, 169-187, 2014.
Zanetti, A., Giovanardi, T., Langone, A., Tiepolo, M., Wu, F. Y., Dallai, L., and Mazzucchelli, M.: Origin and age of zirconbearing chromitite layers from the Finero phlogopite peridotite (Ivrea-Verbano Zone, Western Alps) and geodynamic consequences, Lithos, 262, 58-74, 2016. 